\title{
Inhibition of SARS-CoV-2 infection in human cardiomyocytes by targeting the Sigma-1 receptor disrupts cytoskeleton architecture and contractility
}

José Alexandre Salerno ${ }^{1,2 *}$, Thayana Torquato ${ }^{1 *}$, Jairo R. Temerozo ${ }^{3,4}$, Livia Goto-Silva1, Mayara Mendes ${ }^{1}$, Carolina Q. Sacramento ${ }^{5,6}$, Natalia Fintelman-Rodrigues ${ }^{5,6}$, Gabriela Vitoria $^{1}$, Leticia Souza ${ }^{1}$, Isis Ornelas ${ }^{1}$, Carla Veríssimo ${ }^{2}$, Karina Karmirian ${ }^{1,2}$, Carolina Pedrosa ${ }^{1}$, Suelen da Silva Gomes Dias ${ }^{5}$, Vinicius Cardoso Soares ${ }^{2,5}$, Luiz Guilherme HS Aragão ${ }^{1}$, Teresa Puig-Pijuan ${ }^{1,7}$, Vinícius W. Salazar ${ }^{8}$, Rafael Dariolli, ${ }^{9}{ }^{10}$, Diogo Biagi ${ }^{10}$, Daniel Rodrigues Furtado ${ }^{1}$, Helena L. Borges ${ }^{2}$, Patrícia Bozza ${ }^{5}$, Marília Zaluar Guimarães ${ }^{1,2}$, Thiago Moreno L. Souza ${ }^{5,6}$, Stevens K. Rehen ${ }^{1,2}$.

${ }^{1}$ D'Or Institute for Research and Education (IDOR), Rio de Janeiro, RJ, Brazil.

${ }^{2}$ Institute of Biomedical Sciences, Federal University of Rio de Janeiro (UFRJ), Rio de Janeiro, RJ, Brazil.

${ }^{3}$ National Institute for Science and Technology on Neuroimmunomodulation (INCT/NIM), Oswaldo Cruz Institute (IOC), Oswaldo Cruz Foundation (Fiocruz), Rio de Janeiro, RJ, Brazil.

${ }^{4}$ Laboratory on Thymus Research, Oswaldo Cruz Institute (IOC), Oswaldo Cruz Foundation (Fiocruz), Rio de Janeiro, RJ, Brazil.

${ }^{5}$ Immunopharmacology Laboratory, Oswaldo Cruz Institute (IOC), Oswaldo Cruz Foundation (Fiocruz), Rio de Janeiro, RJ, Brazil.

${ }^{6}$ National Institute for Science and Technology on Innovation in Diseases of Neglected Populations (INCT/IDPN), Center for Technological Development in Health (CDTS), Oswaldo Cruz Foundation (Fiocruz), Rio de Janeiro, RJ, Brazil.

${ }^{7}$ Carlos Chagas Filho Institute of Biophysics, Federal University of Rio de Janeiro (UFRJ), Rio de Janeiro, RJ, Brazil.

${ }^{8}$ Department of Systems and Computer Engineering, COPPE, Federal University of Rio de Janeiro (UFRJ)

${ }^{9}$ Department of Pharmacological Sciences, Icahn School of Medicine at Mount Sinai, New York, NY, USA

10 Pluricell Biotech, São Paulo, SP, Brazil.

* These authors contributed equally to this work.

Corresponding author: Stevens Rehen (srehen@lance-ufrj.org) 


\begin{abstract}
Heart dysfunction, represented by conditions such as myocarditis and arrhythmia, has been reported in COVID-19 patients. Therapeutic strategies focused on the cardiovascular system, however, remain scarce. The Sigma-1 receptor (S1R) has been recently proposed as a therapeutic target because its inhibition reduces SARSCoV-2 replication. To investigate the role of S1R in SARS-CoV-2 infection in the heart, we used human cardiomyocytes derived from induced pluripotent stem cells (hiPSC$\mathrm{CM}$ ) as an experimental model. Here we show that the S1R antagonist NE-100 decreases SARS-CoV-2 infection and viral replication in hiPSC-CMs. Also, NE-100 reduces cytokine release and cell death associated with infection. Because $S 1 R$ is involved in cardiac physiology, we investigated the effects of NE-100 in cardiomyocyte morphology and function. We show that NE-100 compromises cytoskeleton integrity and reduces beating frequency, causing contractile impairment. These results show that targeting S1R to challenge SARS-CoV-2 infection may be a useful therapeutic strategy but its detrimental effects in vivo on cardiac function should not be ignored.
\end{abstract}

Keywords: SARS-CoV-2; iPSC; Cardiomyocyte; Sigma-1 receptor; Cytokines; Contractility 


\section{INTRODUCTION}

COVID-19 is an airborne infectious disease caused by the Severe Acute Respiratory Syndrome Coronavirus 2 (SARS-CoV-2). Since the first patients were diagnosed with COVID-19, myocardial injury following SARS-CoV-2 infection has been reported (C. Huang et al., 2020). Serious lung infection leading to respiratory failure is the main cause of death (Gnecchi et al., 2020; L. Huang et al., 2020; Vincent and Taccone, 2020). However, acute myocardial injury is also ranked as a cause of SARS-CoV-2 infection-related fatalities; Shi and collaborators have shown that the inhospital mortality was increased (of $51.2 \%$ ) in comparison to cases without cardiac injury (of 4.5\%) (Shi et al., 2020). Cardiovascular comorbidities are related to worse outcomes and, together with diabetes, are the most current chronic conditions among hospitalized COVID-19 patients (B. Li et al., 2020; Yang et al., 2020).

SARS-CoV-2 was reported in the myocardial tissue (Lindner et al., 2020; Yao et al., 2020). Whereas some autopsy studies suggested that SARS-CoV-2 infects cardiomyocytes (Bulfamante et al., 2020), others indicated that the most likely targets are interstitial or invading cells in the myocardium (Hoffmann et al., 2020; Lindner et al., 2020). Therefore, it is not a consensus whether the myocardial disease is a direct result of SARS-CoV-2 damage to cardiomyocytes or secondary to systemic events.

Angiotensin-converting enzyme 2 (ACE2) is reported as the main receptor mediating SARS-CoV-2 cell entry (Scialo et al., 2020). ACE2 is expressed in many organs including the heart, where it plays a pivotal role in cardiovascular function ( $\mathrm{Li}$, 2016; Lu et al., 2020; Patel et al., 2016; Shang et al., 2020). The number of ACE2positive cells and the expression of ACE2 itself are increased in failing hearts, which could facilitate SARS-CoV-2 infection (Nicin et al., 2020; Xu et al., 2020). These observations suggest an interplay between the cardiovascular system and susceptibility to infection.

Analyzing the human embryonic heart, Yang and collaborators found that ACE2 is enriched in the cardiomyocyte subset of cells and argue that priming of the SARSCoV-2 Spike protein (SP) probably occurs through host cell cathepsins B and L (CTSB and CTSL) (Yang et al., 2021). Following ACE2 receptor attachment, SARS-CoV-2 utilizes the CTSL-dependent endolysosomal route in human induced pluripotent stem 
cell-derived cardiomyocytes (hiPSC-CMs) (Pérez-Bermejo et al., 2020). The hiPSCCMs reproduce many key features of human myocardial cells and have been recognized as useful tools to address SARS-CoV-2 heart infection in vitro and to test drugs that may eventually prevent cardiac susceptibility (Choi et al., 2020; Marchiano et al., 2020; Pérez-Bermejo et al., 2020; Sharma et al., 2020).

Several compounds with antiviral activity have been proposed against SARSCoV-2 infection, especially from drug repurposing studies (Lovato et al., 2020; Reznikov et al., 2020; Vela, 2020). Negative modulators of the Sigma-1 receptor (S1R) gained considerable attention in SARS-CoV-2 infection because of its interaction with non-structural protein 6 (NSP6) from SARS-CoV-2 (Gordon et al., 2020). S1R binds ligands with very diverse structures from a wide spectrum of compounds and small molecules (Su et al., 2010; Tesei et al., 2018). Experimental and approved drugs that bind Sigma receptors with mild to high affinity, even as an off-target, have been considered to prevent or treat COVID-19 (Reznikov et al., 2020; Vela, 2020). Several of these compounds that inhibit S1R function have antiviral activity, including against other coronaviruses, but cardiotoxicity and induction of arrhythmias were also reported (Chen et al., 2006; Page et al., 2016).

On the other hand, apart from antiviral activity and participation in cardiac function, S1R activation has also drawn attention for its potential anti-inflammatory properties that could control the hyperinflammatory damage that follows severe SARSCoV-2 infection (Troncone, 2020). Recently, a randomized placebo-controlled clinical trial showed that the S1R agonist fluvoxamine prevents clinical deterioration of symptomatic COVID-19 patients (Lenze et al., 2020). Indeed, S1R activity is frequently described as an inhibitory pathway of cytokine production via inositol-requiring enzyme 1-alpha (IRE1-a)(Rosen et al., 2019a). As a result of this downstream signaling, S1R stimulation was demonstrated to protect mice from septic shock. As current evidence shows that the outpouring of inflammatory cytokines at the late stages of critical COVID-19 cases has a clear correlation with severity of symptoms and poor prognosis (X. Li et al., 2020), is of utmost relevance to consider both antiviral and antiinflammatory approaches for potential drug candidates.

The modulation of S1R is in the spotlight of alternative pharmacological approaches in COVID-19 but remains to be explored. In this study, we investigated 
the role of S1R in SARS-CoV-2 infection of hiPSC-CMs. Inhibition of S1R reduced SARS-CoV-2 infection and viral replication, preventing infection-associated cell death and cytokine release. On the other hand, it led to aberrant changes in the cytoskeleton and impaired cellular contraction. These results suggest that targeting S1R as a strategy against COVID-19 should be considered carefully regarding possible adverse cardiac outcomes.

\section{RESULTS}

\subsection{Human induced pluripotent stem cell-derived cardiomyocytes (hiPSC-CMs) express the cardiac-specific troponin T and S1R}

Human cardiomyocytes were differentiated from induced pluripotent stem cells (iPSCs) according to established protocols(Cruvinel et al., 2020). Differentiation to cardiomyocytes resulted in a cell population with low expression of the pluripotency marker OCT-4 $(0.8 \% \pm 0.4 \%)$ and most cells expressing the specific cardiac muscle marker troponin T (cTnT) $(88.4 \% \pm 8.4 \%)$, as assessed by flow cytometry (Figure 1A). The presence of cTnT was confirmed by immunostaining and cytoskeleton cell morphology can be visualized by F-actin staining (Figure 1B). Sigma receptors are known to be expressed in rat heart cells, especially the S1R subtype(Novakova et al., 1995). Here, we showed S1R expression in human cardiomyocytes by western blot (Figure 1C) and observed by immunostaining that S1R is widely spread within cells with an enhanced signal in the perinuclear region and the nuclei (Figure 1D). This is consistent with the cellular distribution of S1R in other cell types from rodents (Hayashi and Su, 2003). 
A

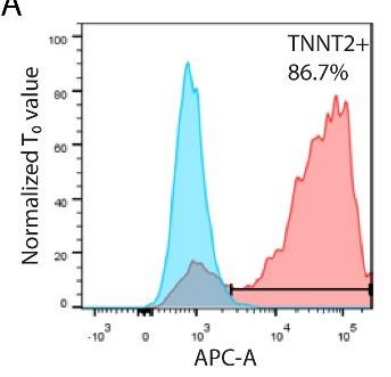

C

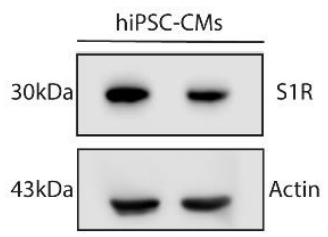

B

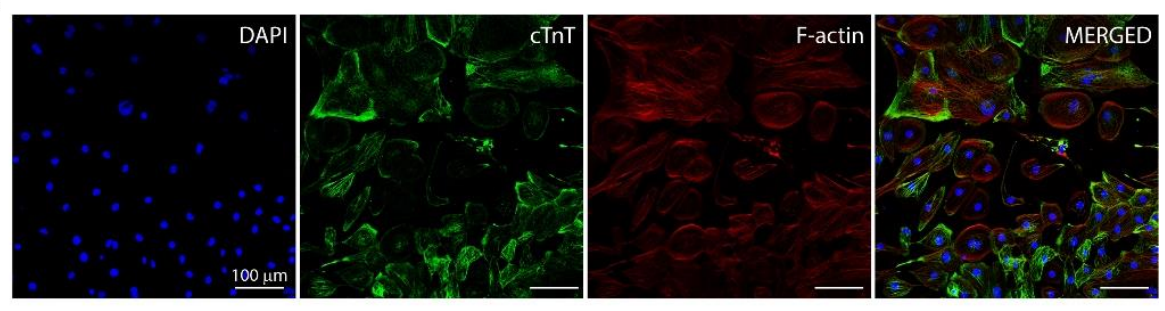

D

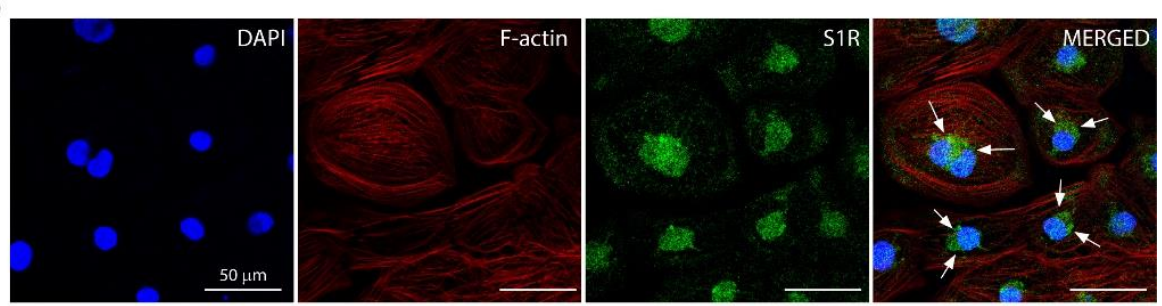

Figure 1. Human induced pluripotent stem cell-derived cardiomyocytes (hiPSC-CMs) express the specific cardiac Troponin T (cTnT) marker and the Sigma-1 receptor (S1R). (A) Flow cytometry data representing the expression of cardiac-specific marker troponin T (cTnT/TNNT2), confirming highly efficient differentiation into cardiomyocytes. (B) Immunocytochemistry for CTnT and phalloidin staining for filamentous actin (F-actin). Anti-cTnT (green); phalloidin (red) and nuclei (blue); scale bar $=100 \mu \mathrm{m}$. (C) Western blotting of S1R in protein extracts of control hiPSC-CMs performed in duplicate. Actin was used as a loading control. (D) Immunocytochemistry for S1R in hiPSC-CMs. Nuclear and perinuclear regions (white arrows). S1R (green); phalloidin (red) and nuclei (blue); scale bar $=50 \mu \mathrm{m}$.

\subsection{Inhibition of S1R reduces SARS-CoV-2 infection and replication in human cardiomyocytes and prevents cell death}

To inhibit S1R in hiPSC-CMs, cells were treated with the high-affinity S1R antagonist NE-100, which has a very low affinity for other receptors such as dopamine, serotonin, and phencyclidine receptors (Okuyama et al., 1993). NE-100 does not show toxicity at concentrations ranging from $10 \mathrm{nM}$ to $10 \mu \mathrm{M}$ after $72 \mathrm{~h}$ (Supplemental Figure 1 A). Also, hiPSC-CMs treated with $1 \mu \mathrm{M} \mathrm{NE}-100$ for $48 \mathrm{~h}$ and $72 \mathrm{~h}$ showed no significant changes in the number of pyknotic nuclei, which represents an irreversible chromatin-condensed nuclear state characteristic of cell death (Supplemental Figure $1 \mathrm{~B})$.

Following $24 \mathrm{~h}$ pretreatment with $1 \mu \mathrm{M} \mathrm{NE}-100$, hiPSC-CMs were infected with SARS-CoV-2 and the infection rate was evaluated at 48 hours post-infection (h.p.i). Immunofluorescence using convalescent serum (CS) from a recovered COVID-19 
patient showed that $57.3 \%( \pm 11.1 \%)$ of cells were infected at 48 h.p.i (Figure 2A). We confirmed that CS-staining mostly co-localizes with the specific SARS-CoV-2 Spike Protein (SP) (Supplemental Figure 2). Importantly, S1R inhibition reduced the percentage of infected hiPSC-CMs to $35.8 \%$ ( $\pm 2.5 \%$ ) (Figure $2 \mathrm{~A}$ and B).

Infection of hiPSC-CMs with SARS-CoV-2 led to the production of infectious virions as shown in Figure 2C. Exposure to NE-100 significantly diminished viral yield, with an average reduction of $82 \%$ at 48 h.p.i (Figure 2C). SARS-CoV-2 infection was shown to induce cytopathic features in hiPSC-CMs, mostly related to myofibrillar disruption and sarcomeric fragmentation, as described by Pérez-Bermejo and collaborators (Pérez-Bermejo et al., 2020). Likewise, we detected a pattern of fragmentation at 48 h.p.i, as shown in Supplemental Figure 3 with cardiac TnT staining.

Lactate dehydrogenase (LDH) release was evaluated in hiPSC-CM cultures and confirmed that SARS-CoV-2 infection causes cardiomyocyte death, as previously reported (Sharma et al., 2020). At 24, 48 and 72 h.p.i, LDH levels in cell supernatants were elevated in SARS-CoV-2-infected conditions when compared to mock controls by 2.3, 5.6 and 2.7-fold respectively (Figure 2D). NE-100 significantly decreases LDH leakage at 48 and 72 h.p.i (Figure 2D). These results suggest that the inhibition of S1R may prevent hiPSC-CMs death by decreasing susceptibility to infection. 
A

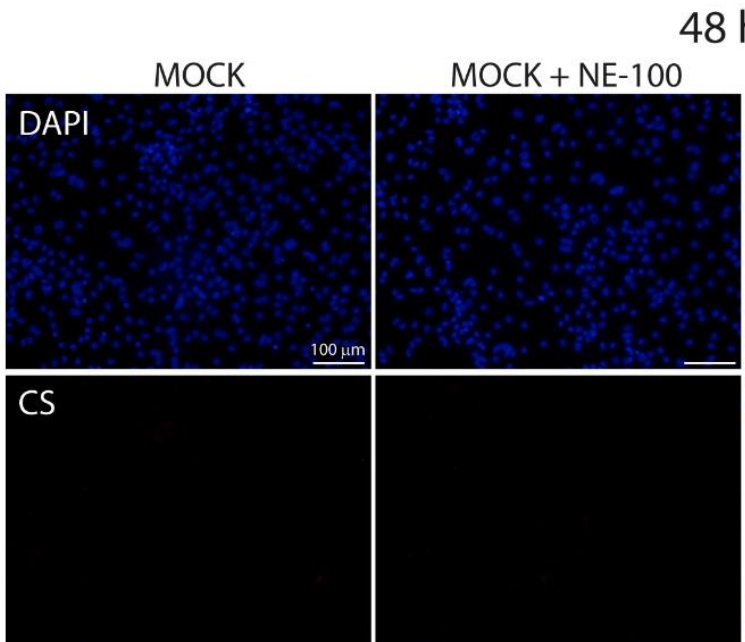

48 h.p.i
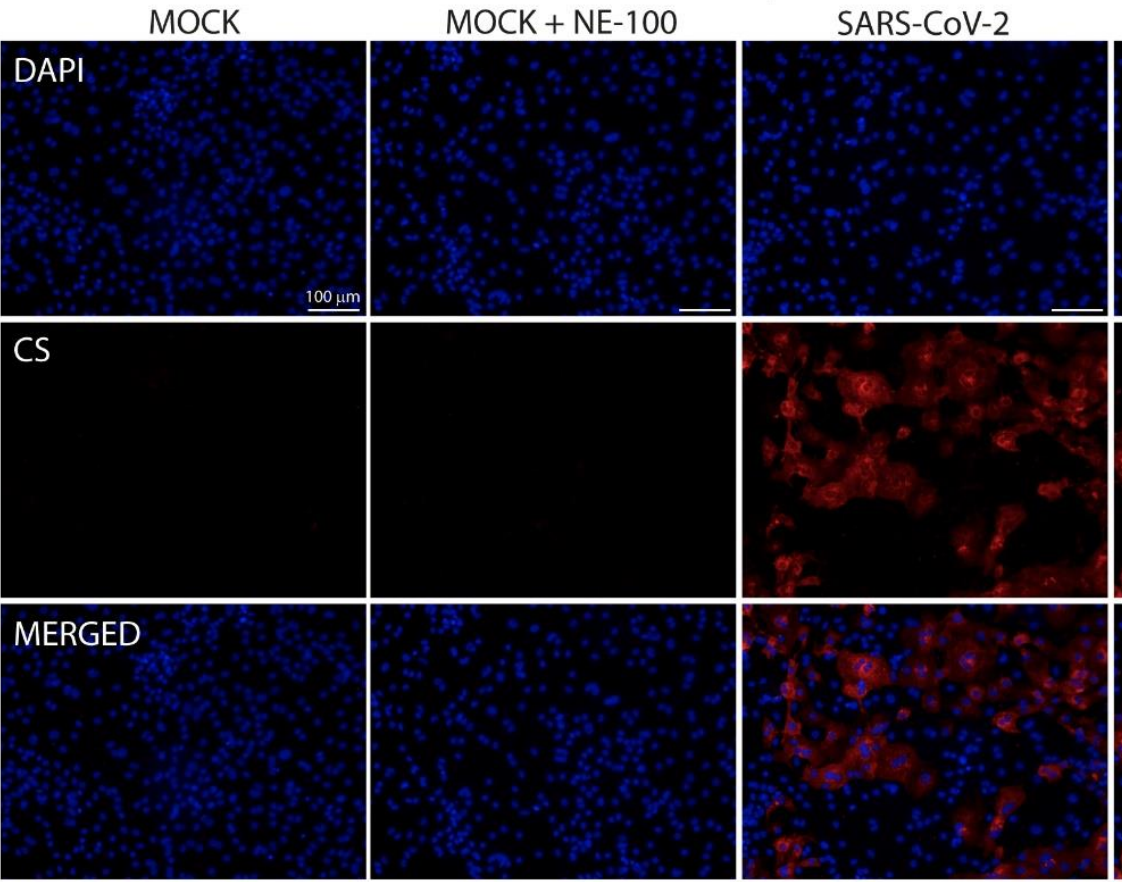

SARS-CoV-2 + NE-100

B

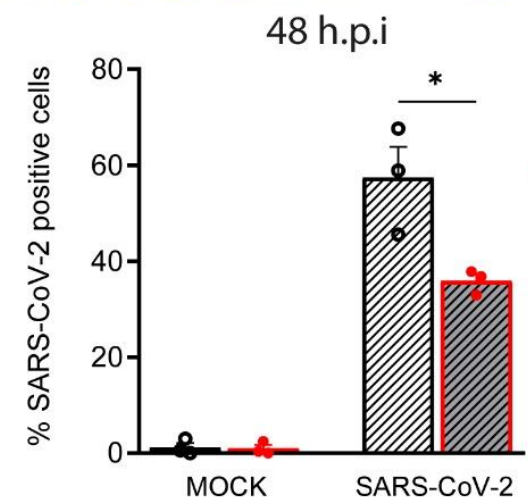

Untreated

II] NE-100 $1 \mu \mathrm{M}$

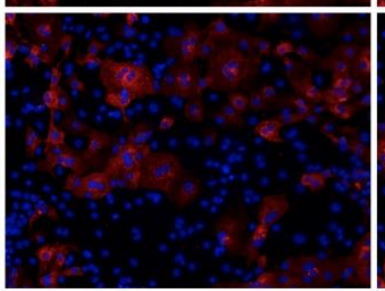

C

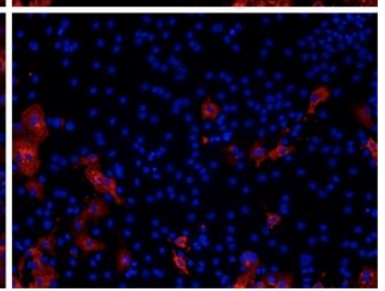

48 h.p.i

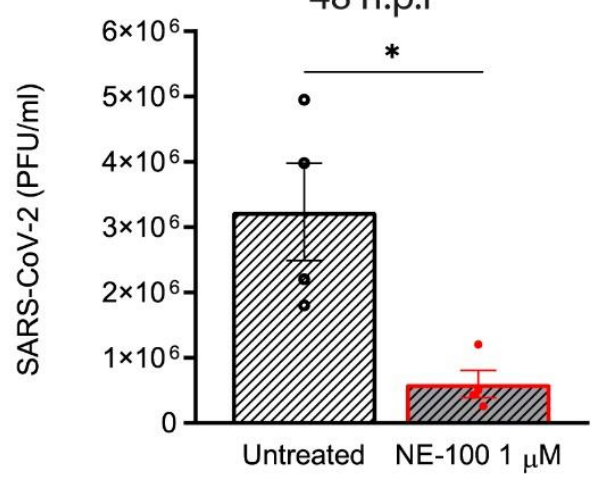

D

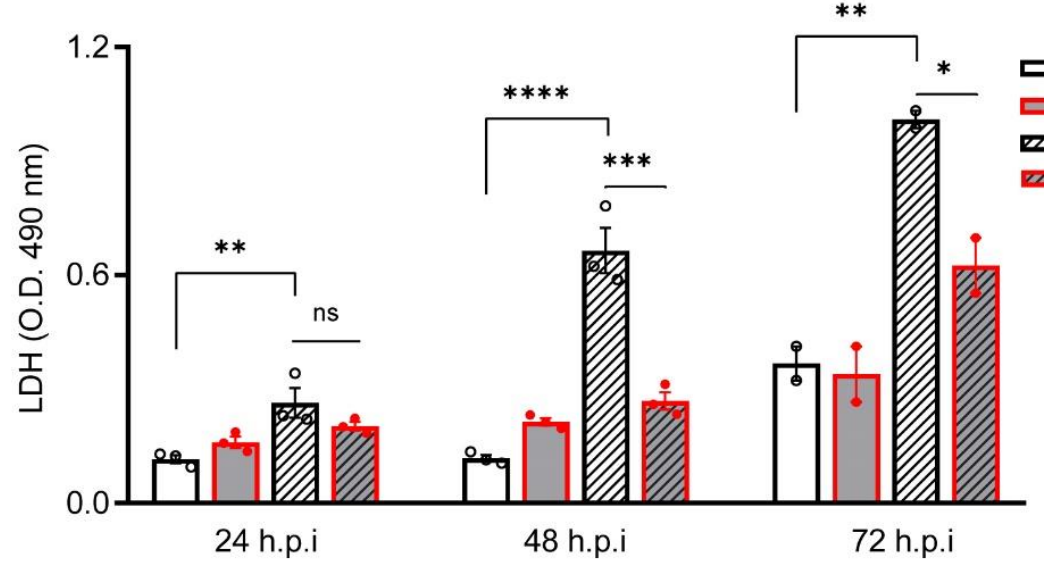

Figure 2. S1R inhibition reduces SARS-CoV-2 infection, replication and cytotoxicity in hiPSCCMs. (A) hiPSC-CMs were pre-treated for $24 \mathrm{~h}$ with $1 \mu \mathrm{M} \mathrm{NE}-100$ and infected with SARS-CoV-2 at multiplicity of infection (MOI) of 0.1 . Cells were evaluated at 48 hours post-infection (h.p.i). Immunostainings show infected hiPSC-CMs positively stained for convalescent serum (CS) in red and no signal detection in mock conditions; scale bar $=100 \mu \mathrm{m}$. (B) The percentage of infected hiPSC- 
CMs was assessed by quantification of CS positive cells in SARS-CoV-2-infected and mock-infected conditions exposed or not to S1R high-affinity antagonist NE-100. (C) Plaque forming units assay for the supernatants of the SARS-CoV-2 infected hiPSC-CMs. (D) Cell death was measured in the supernatant by LDH activity at 24,48 and 72 h.p.i. Data are represented as the mean \pm S.E.M obtained in at least three independent experiments. ${ }^{*} p<0.05,{ }^{* *} p<0.01,{ }^{* * *} p<0.001,{ }^{* \star *} p<0.0001$.

Since S1R is engaged in ER protein synthesis and acts as chaperone for proteins translocating to cell surface (Vela, 2020), we investigated whether S1R inhibition could be related to modifications of the host cell receptor for viral entry. To that end, the expression of ACE2 was evaluated after a $24 \mathrm{~h}$ treatment with $1 \mu \mathrm{M}$ of S1R antagonist NE-100. We observed a reduction in the levels of ACE2 mRNA, not statistically significant $(P=0.0790)$ (Supplemental Figure 4A). Western blot analysis of ACE2 after NE-100 treatment did not show differences at the protein level (Supplemental Figures 4B and C). These data suggest that the inhibition of SARSCoV-2 infection in hiPSC-CMs can occur through mechanisms other than a reduction in the availability of ACE2 under the above described NE-100 exposure.

\subsection{S1R inhibitor NE-100 attenuates cytokine release in SARS-CoV-2 infected hiPSC-CMs}

Cell death is probably the final denouement to hiPSC-CMs at 72 h.p.i (Sharma et al., 2020). To investigate early events before cell death, we analyzed the levels of some of the main cytokines associated with COVID-19 at 24 and 48 h.p.i. We found that SARS-CoV-2 infection increased the release of interleukin (IL)-6 when compared to control. NE-100 decreased the release of interleukin (IL-6) at 24 h.p.i (Figure 3A). At 48 h.p.i, IL-6 increased 4-fold in comparison to control. Similarly, NE-100 decreased the release of IL-6 (Figure 3B).

No distinctly clear differences in the IL-8 secretion pattern were apparent at 24 h.p.i (Figure 3A). However, at 48 h.p.i, SARS-CoV-2 increased IL-8 amount by 5.5fold relative to mock condition (Figure 3B). Comparably to the modulation of IL-6 levels, NE-100 robustly decreased IL-8 secretion (Figure 3B). Tumor necrosis factoralpha (TNF- $\alpha$ ) was also measured and found increased only at 24 h.p.i (3.3-fold), when the NE-100 treatment restored secretion to similar levels of control condition (Figure 3A), while no significant changes were observed at 48 h.p.i (Figure 3B). 
A

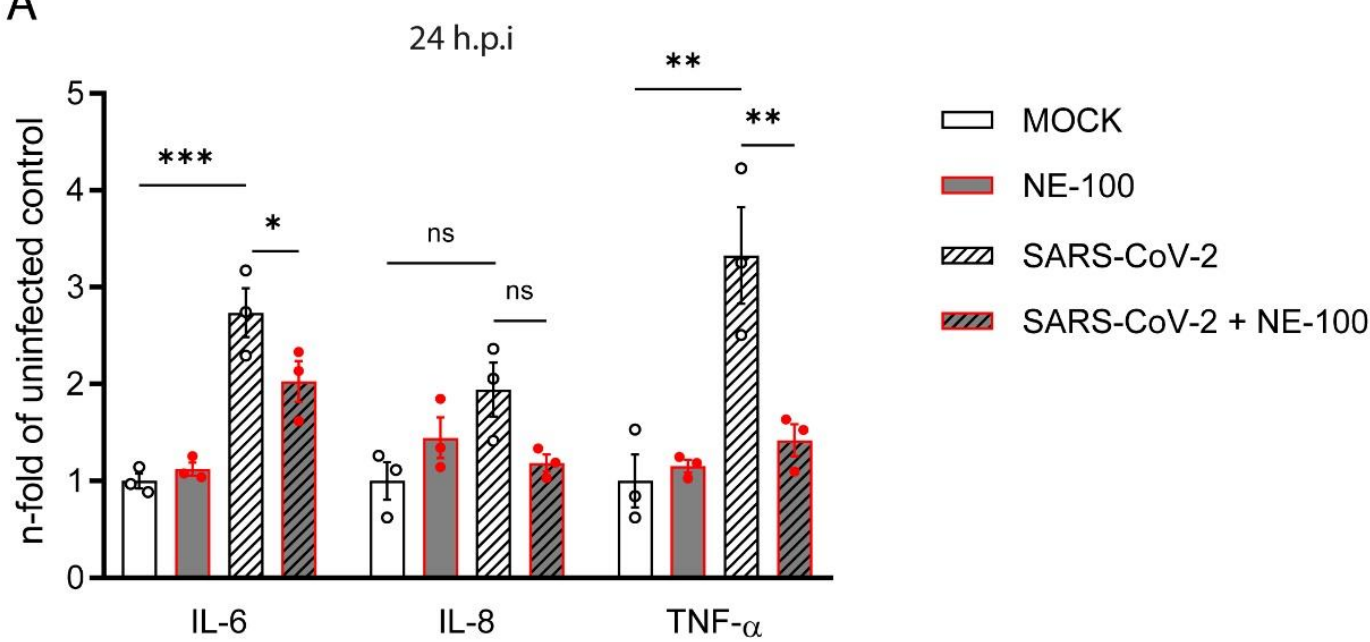

B

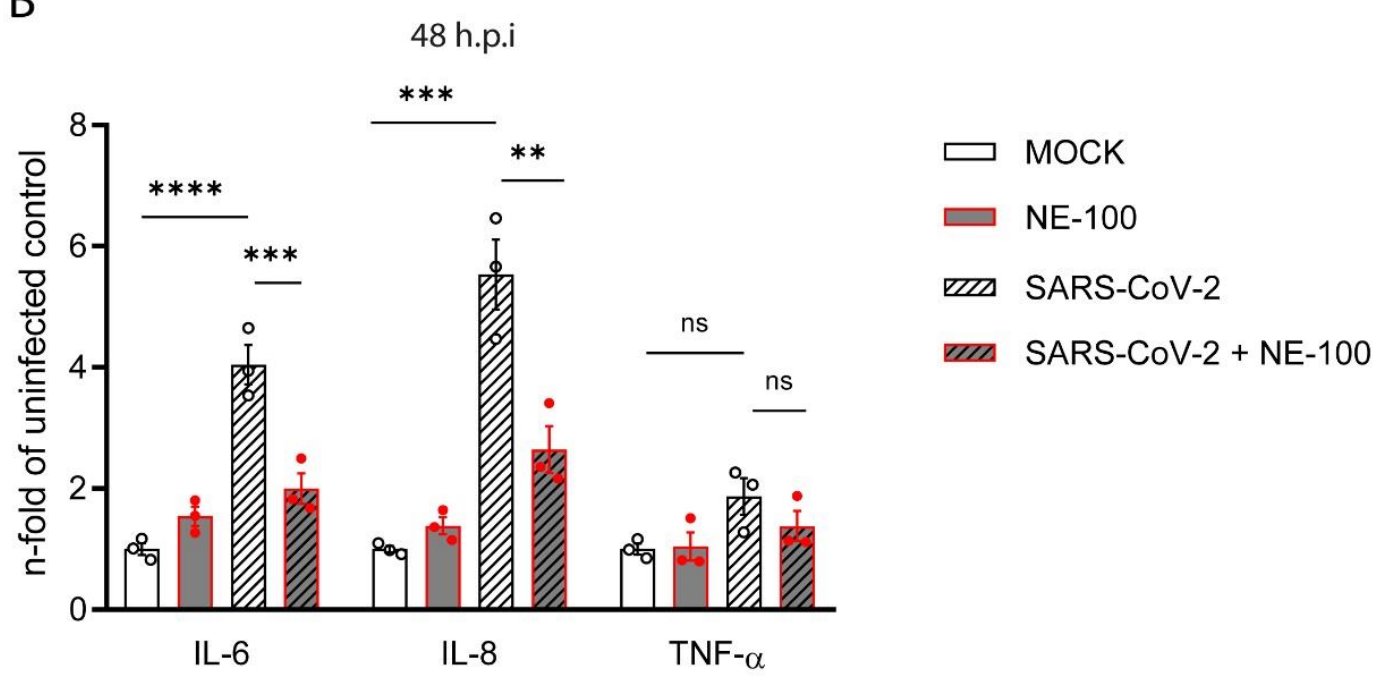

Figure 3. NE-100 decreases cytokine release that follows SARS-CoV-2 infection in hiPSC-CMs. (A and B) hiPSC-CMs were pre-treated or not with NE-100 and infected with SARS-CoV-2. Supernatants were analyzed by ELISA for IL-6, IL-8 and TNF- $\alpha$ at 24 h.p.i (A) and 48 h.p.i (B). Data represent mean \pm SEM from three independent experiments. ${ }^{*} p<0.05,{ }^{* *} p<0.01,{ }^{* * *} p<0.001,{ }^{* * * *} p<$ 0.0001 .

\subsection{S1R inhibition disrupts cytoskeleton architecture and contractility of human cardiomyocytes}

One of the main features displayed by cultured cardiomyocytes is their ability to perform spontaneous contractions (Belostotskaya and Golovanova, 2014). In that matter, hiPSC-CMs were proved to be a suitable model to evaluate drug-induced changes in contractility (Niehoff et al., 2019; Pointon et al., 2015). We observed a 
decrease from $17.7( \pm 5.9)$ beats per minute $(\mathrm{bpm})$ to $6.7( \pm 1.8) \mathrm{bpm}$ and from 14.7 $( \pm 2.8) \mathrm{bpm}$ to 4.1 ( \pm 0.8$) \mathrm{bpm}$ after $24 \mathrm{~h}$ and $48 \mathrm{~h}$ of NE-100 exposure, respectively (Figure 4A and Supplemental videos). These results suggest that the inhibition of $\mathrm{S} 1 \mathrm{R}$ leads to contractile impairment and a putative functional collapse.

S1R plays a cardioprotective role during maladaptive cardiac remodeling and the anti-hypertrophic properties of S1R agonists have been extensively described (Hirano et al., 2014; Tagashira et al., 2013; Tagashira and Fukunaga, 2012). Therefore, we also investigated if the S1R antagonist NE-100 alone could induce a hypertrophic response that could lead to contractile machinery overload and beating frequency reduction. To that end, we evaluated gene expression upon S1R inhibition, measuring mRNA levels of the atrial natriuretic peptide (ANP), which is one of the main transcripts of the fetal program for cardiac growth. ANP overexpression is frequently correlated to cardiac hypertrophy and NE-100 decreased mRNA expression of ANP by 1.49-fold after $24 \mathrm{~h}$ (Figure 4B). Next, we evaluated cell size and no increase in the average cell surface area of hiPSC-CMs was observed by F-actin staining. In fact, NE-100 exposure decreased the average cell surface area after 48 h (Figure 4C), which is a phenotype opposite to the expected for cardiomyocyte hypertrophic responses in vitro (Watkins et al., 2012).

We then hypothesized that the reduction in beating frequency could be related to cell shrinking and attributed to morphological changes induced by S1R inhibition. Analysis of cardiac troponin (cTnT) staining revealed a significant decrease both in cTnT immunoreactive area and fluorescence intensity of hiPSC-CMs exposed to NE100 when compared to untreated controls (Figure 4D and E, respectively). These results are probably attributable also to a decrease in cellular cTnT content rather than exclusively to a change in cell area, indicating a noticeable loss of troponin. In addition, the integrity of cytoskeletal fibers was grossly affected, as shown in confocal fluorescence images (Figure 4F). 
A



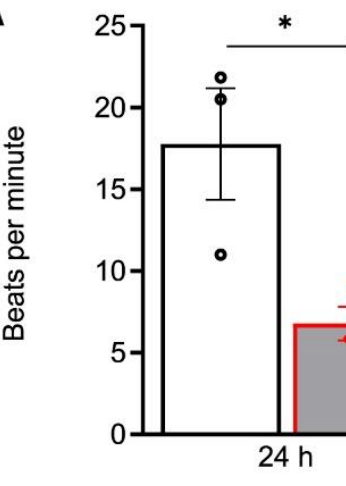

C

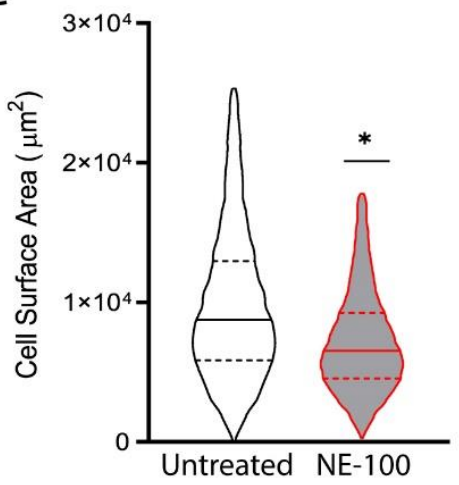

$\mathrm{D}$

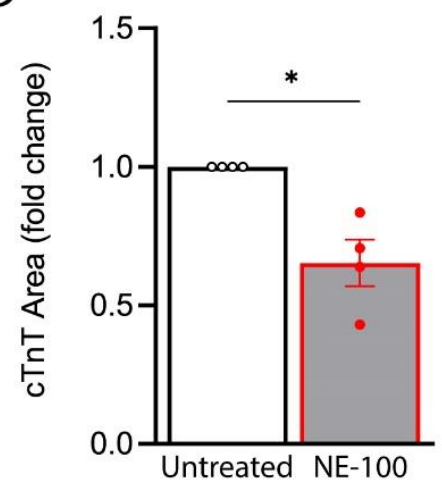

B

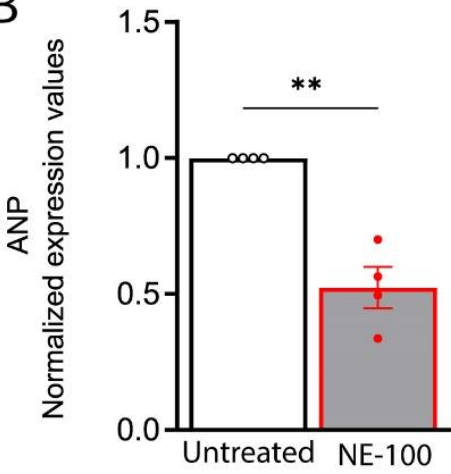

$\mathrm{E}$

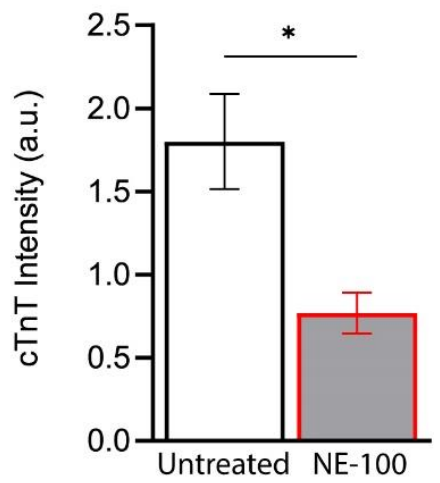

$\mathrm{F}$
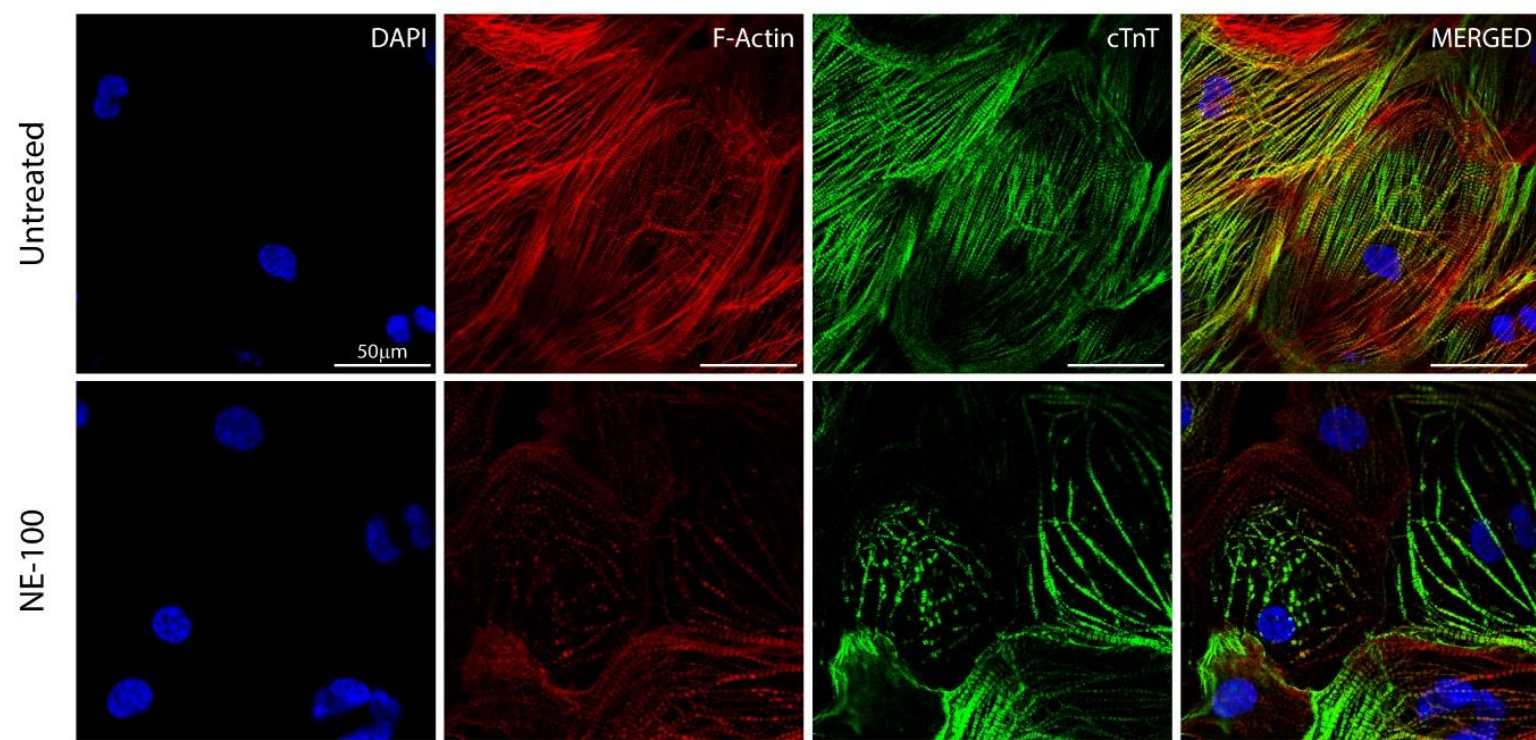

Figure 4. NE-100 decreases beating frequency and disrupts cytoskeleton integrity in hiPSC-CMs. (A) Average of beats per minute analyzed after exposure to NE-100, from three independent experiments. (B) Real-time PCR shows decreased levels of transcript content for ANP after S1R inhibition. (C) Cell area was quantified by F-actin staining and shows a decrease in cell body sizes after exposure to NE-100 for 48 h. (D and E) Quantification of cTnT immunoreactive area and intensity, normalized by the total number of cells per field; values are expressed relative to untreated controls. (F) Confocal images show in more detail 
the disruption of F-actin and cTnT organization. Scale bar $=50 \mu \mathrm{m}$. Data is presented as the average \pm S.E.M from at least three independent assays. ${ }^{*} p<0.05 ;{ }^{* *} p<0.01$

Since there are changes in the cytoarchitecture, but not in cell toxicity or hypertrophy induction, we suggest that cytoskeleton disruption is the most likely cause for contractile collapse of hiPSC-CMs induced by S1R inhibition.

\section{DISCUSSION}

In this study, we show that hiPSC-CMs are permissive to a SARS-CoV-2 productive infection, corroborating previous results and validating this model to study COVID-19 cardiac pathology in vitro (Bojkova et al., 2020; Bulfamante et al., 2020; Choi et al., 2020; Marchiano et al., 2020; Pérez-Bermejo et al., 2020; Sharma et al., 2020). Cell-based anti-SARS-CoV-2 drug screenings have been widely performed and the hiPSC-CMs approach is improving rapidly so that it can support the prediction of cardiac side effects at early preclinical steps of drug development (Chaudhari et al., 2016; Mirabelli et al., 2020; Yiangou et al., 2020).

We described that S1R inhibition with the high-affinity antagonist NE-100 decreases the number of SARS-CoV-2-infected hiPSC-CMs by $21.5 \%$ and viral yield by $82 \%$ at 48 h.p.i. Sharma and colleagues previously described increased cell death through apoptosis in hiPSC-CMs after SARS-CoV-2 infection (Sharma et al., 2020). Here, we confirmed the cytotoxic effect of the virus providing evidence to support that direct damage to cardiomyocytes follows SARS-CoV-2 infection and could be related to cardiac injury in COVID-19.

Broader time point analyses are still needed to rule out an ACE2-dependent inhibition of infection by S1R antagonism. However, there is no description of direct interaction between S1R and host proteins involved in SARS-CoV-2 attachment or viral envelope proteins (Vela, 2020). Moreover, the assumption of a blockage mechanism after cell entry is in agreement with the SARS-CoV-2-human protein interaction map based on proteomics analysis, whereupon SARS-CoV-2 NSP6, located at the ER, interacts directly with human S1R (Gordon et al., 2020). During the replication of mammalian coronaviruses, this viral protein orchestrates vesicle trafficking and regulates ER remodeling (Cottam et al., 2011; J Alsaadi and Jones, 2019). This close relationship with S1R could be related to its activity in the 
rearrangement of endomembrane compartments and trafficking to favor steps of the replication of SARS-CoV-2 (Gordon et al., 2020; Santerre et al., 2020).

Gordon and colleagues assessed the antiviral activity of sigma receptor ligands in Vero E6 cells, which are highly permissive to infection. The authors described that those with antagonist action reduced viral infectivity by targeting replication (Gordon et al., 2020). Moreover, they reported that the S1R agonist dextromethorphan had proviral activity. Herein, we provide evidence to support that this is also true for human cardiac cells in vitro. Interestingly, compounds believed to protect from SARS-CoV-2 infection that are currently undergoing clinical trials, such as chloroquine (phase 2 NCT04349371), have S1R as an off-target (Hirata et al., 2011).

$\mathrm{S} 1 \mathrm{R}$ is critical for early steps of Hepatitis C Virus (HCV) RNA replication so that its downregulation decreases susceptibility to infection in the hepatocyte-derived carcinoma cell lineage Huh-7 (Friesland et al., 2013). A hallmark of these positivesense single-stranded RNA viruses, such as HCV and SARS-CoV-2, is that replication occurs inside modified membranes derived from the ER, where S1R is mostly expressed (Miller and Krijnse-Locker, 2008; Mori et al., 2013; Ritzenthaler and Elamawi, 2006). Approved drugs with antiviral activity against HCV replication have been demonstrated to be potential repurposed compounds to fight SARS-CoV-2 infection in vitro (Sacramento et al., 2020). Notably, remdesivir, which is an efficient antiviral drug against HCV, was approved for emergency treatment of COVID-19 patients requiring hospitalization (Eastman et al., 2020). Remdesivir anti-SARS-CoV2 activity in human cardiomyocytes was described by Choi and colleagues, together with a safety profile evaluation that stipulated considerable arrhythmogenic and cardiotoxic risk in vitro, raising the concern of drug-induced cardiotoxicity of repositioned pre-approved compounds to manage COVID-19 (Choi et al., 2020).

Aside from viral infection and replication, the immune-mediated mechanisms are a hallmark of COVID-19 pathology and associated cardiac deterioration that can be successfully modeled using hiPSC-CMs (Azkur et al., 2020; Dariolli et al., 2021). Along with monocytes and fibroblasts, cardiomyocytes are also an important source of cytokines during events such as heart failure (Aoyagi and Matsui, 2012). Here, we showed that IL-6, IL-8 and TNF- $\alpha$ release is stimulated in hiPSC-CMs in response to SARS-CoV-2 infection, complementing previous data on increased mRNA levels of these cytokines (Wong et al., 2020). Elevated levels of IL-6 are strongly correlated with cardiac damage and heart failure in rodent models (Janssen et al., 2005; Jug et 
al., 2009). Moreover, previous reports demonstrated that IL-6 produced in cardiomyocytes promotes inflammation in the heart by recruiting neutrophils (Youker et al., 1992). Interestingly, IL-8, which was also found increased, is a neutrophil chemotactic factor correlated with chronic heart failure, coronary heart disease and myocardial apoptosis (Akasaka et al., 2006; Nymo et al., 2014; Rothenbacher et al., 2006). Indeed, myocardial infiltration of neutrophils has been reported in the hearts of COVID-19 patients and is believed to be a key mechanism behind myocardial damage (Yao et al., 2020).

The consequences of infection to cardiomyocytes are just beginning to be unraveled in vitro and should help to better understand COVID-19 heart pathology and its crosstalk with systemic events of disease progression. Our results suggest that immunopathological mechanisms probably underlie myocardial injury following SARSCoV-2 infection and that cardiomyocytes could also play a role in the excessive systemic release of cytokines observed in the late stages of COVID-19. Interestingly, S1R inhibition with NE-100 attenuated the cytokine release following SARS-CoV-2 infection. However, the anti-inflammatory role promoted by S1R activation in the control of septic shock and its immunomodulatory activity during infections by other respiratory viruses, such as $\mathrm{H} 1 \mathrm{~N} 1$ influenza virus, have been well described (Rosen et al., 2019b; Szabo et al., 2014; Zhou et al., 2019). Therefore, the effect observed in this work is more likely to be due to the inhibition of infection than a direct effect on cytokine production.

Although S1R antagonism was an efficient mechanism to diminish SARS-CoV2 infection and associated cell-death and cytokine release, there are reasons to believe that such inhibition could be detrimental to cardiac physiology (Shinoda et al., 2016b, 2016a). Also, as COVID-19 patients are expected to present cardiac dysfunctions (Magadum and Kishore, 2020; Wu et al., 2020), the use of drugs with potential cardiac negative effects could be unfeasible as a therapeutic approach.

Notwithstanding, the cell survival rate was not affected, and neither the characteristic hypertrophic gene expression profile nor enlargement of cell body sizes was detected after NE-100 exposure. Our findings show that inhibition of S1R significantly reduced beating frequency in hiPSC-CMs and completely compromised cell morphology with a conspicuous perturbation of cytoskeletal architecture and decrease in cardiac troponin staining. Actin subunits are assembled into F-actin, which 
serves as a platform for troponin-tropomyosin binding for proper sarcomere function during contraction (Gunning et al., 2015). The integrity of actin and troponin fibers dictates the mechanical stability necessary for proper force distribution at sarcomere margins during contraction and appropriate anchorage between cytoskeletal proteins and extracellular matrix (Gunning et al., 2015). The disruption of cytoskeletal and sarcomeric proteins by a decrease in expression or anomalous arrangement could underlie the pathogenesis of cardiomyopathies and heart failure (Sequeira et al., 2014).

It could be argued that hiPSC-CMs are too immature to reliably predict heart response to NE-100. However, the S1R antagonist haloperidol was demonstrated to prolong QT interval, deplete ATP production and cause shortening of action potentials using cardiomyocytes from different sources, including adult rodents (Shinoda et al., 2016a; Stracina et al., 2015; Tarabová et al., 2009). These observations were consistent with the deterioration of heart function in animal models. Furthermore, S1R knockout mice exhibit maladaptive morphological cardiac remodeling and thereafter contractile dysfunction (Abdullah et al., 2018).

Further investigations are needed to determine whether NE-100 might induce cardiotoxicity in vivo. However, it is hypothesized that the direct interaction between S1R and the human Ether-à-go-go Related Gene (hERG) voltage-gated potassium channel could underlie the blockage of hERG function by S1R ligands, causing delays in cardiac repolarization, impairment of rate adaptation and increased risk for druginduced arrhythmia (Balasuriya et al., 2014; Corbera et al., 2006; Crottès et al., 2011; Eng et al., 2016; Hancox and Mitcheson, 2006; Morales-Lázaro et al., 2019; Witchel, 2011; Yu et al., 2015).

Besides cytoskeleton-sarcomere framework integrity, the contractile capacity of cardiomyocytes is related to calcium availability (Van der Velden et al., 2003). As S1R is a key regulator of intracellular calcium homeostasis, the possibility that blocking its function could be hampering proper calcium cytoplasmic availability and impairing contraction cannot be ruled out, since this was not evaluated at the present work. However, the involvement of calcium intracellular concentration in S1R function in cardiac cells is controversial. Despite the previously described interaction of S1R inhibitors with L-type calcium channels in rat cardiomyocytes, the sensitivity of the myofilaments to calcium ions was shown not to be changed, while beating frequency 
variations followed by asymmetrical contractions were observed after exposure to S1R antagonists (Ela et al., 1994; Tarabová et al., 2009).

$S 1 R$ has been extensively studied regarding its vital role for physiological cardiac function, amelioration of ER stress, and protection against maladaptive hypertrophy that leads to heart failure (Bhuiyan and Fukunaga, 2009; Tagashira et al., 2013; Tagashira and Fukunaga, 2012) but the role of S1R in human cardiomyocytes remains poorly described. Here, we provide data about the involvement of S1R in SARS-CoV-2 replication. Our in vitro results suggest that the inhibition of S1R as a therapeutic strategy against COVID-19 should be further investigated and undergo well-balanced decision-making when translated to clinical application, due to the concern of possible drug-induced cardiac malfunction.

\section{MATERIAL AND METHODS}

\section{1 hiPSC-CMs differentiation, purification, and maintenance}

Fresh human iPSCs-derived cardiomyocytes were purchased from Pluricell (São Paulo, Brazil) and the protocol for cardiomyocyte differentiation is described in detail by Cruvinel and colleagues (Cruvinel et al., 2020). Briefly, hiPSCs were passed and replated to be maintained in E8 medium with $5 \mu \mathrm{M}$ of $\mathrm{Y}-27632$ (Cayman Chemical, USA) with daily changes of media. After $100 \%$ confluence was reached, cells were kept in RPMI supplemented with B27 without insulin (both from Thermo Fisher, USA) and with $4 \mu \mathrm{M}$ CHIR99021 (Merck Millipore Sigma, USA) for one day. After $24 \mathrm{~h}$, the medium was supplemented with $10 \mathrm{ng} / \mathrm{ml}$ BMP4 (R\&D Systems, USA) for an additional $24 \mathrm{~h}$. On day 2, fresh medium was supplemented with $2.5 \mu \mathrm{M} \mathrm{KY} 2111$ and XAV939 (both from Cayman Chemical, USA). From day 4, cells were cultivated with CDM3 media (RPMI supplemented with $213 \mu \mathrm{g} / \mathrm{ml}$ ascorbic acid (Sigma Aldrich, USA), $500 \mu \mathrm{g} / \mathrm{ml}$ Bovine Serum Albumin (BSA) and $2 \mu \mathrm{g} / \mathrm{ml}$ Plasmocin (InvivoGen, USA). On day 18, cells were passaged with TrypLE 10X and plated on a density of $0.9 \times 10^{4} /$ well or $1.8 \times 10^{4}$ /well onto 96 or 24-well plates and maintained in CDM3 media. Upon arrival, cardiomyocytes were allowed to regain contractility and maintained at $37^{\circ} \mathrm{C}$ in a humidified atmosphere with $5 \%$ CO2. Cardiomyocytes were used between days 30 to 40 of differentiation. 


\subsection{Chemicals}

4-Methoxy-3-(2-phenylethoxy)-N,N-dipropylbenzeneethanamine hydrochloride (NE-100 hydrochloride) was purchased from Tocris (3133). Stock and work solutions were prepared using 100\% dimethyl sulfoxide sterile-filtered (DMSO; D2650 - SigmaAldrich).

\subsection{Flow Cytometry}

Cardiomyocytes were plated on 6-well plates coated with GELTREX and cultivated for 7 days. After cell dissociation, cells were fixed with $1 \%$ paraformaldehyde (PFA), permeabilized with Triton 0.1\% (Sigma Aldrich) and Saponin 0.1\% (Sigma Aldrich), and stained with the antibodies anti-TNNT2 (1:2500; Thermo Fisher, MA512960) and anti-OCT4 (1:200, Thermo Fisher, MA5-14845). FC data was acquired using a Canto BD flow cytometer for each batch of differentiation and analyzed using the FlowJo Software considering $1 \%-2 \%$ of false-positive events.

\subsection{SARS-CoV-2 propagation}

SARS-CoV-2 was expanded in Vero E6 cells from an isolate obtained from a nasopharyngeal swab of a confirmed case in Rio de Janeiro, Brazil (GenBank accession no. MT710714). Viral isolation was performed after a single passage in cell culture in $150 \mathrm{~cm}^{2}$ flasks with high glucose DMEM plus 2\% FBS. Observations for cytopathic effects were performed daily and peaked 4 to 5 days after infection. All procedures related to virus culture were handled in biosafety level 3 (BSL3) multi-user facilities according to WHO guidelines. Virus titers were determined as plaque-forming units (PFU/ml), and virus stocks were kept in $-80^{\circ} \mathrm{C}$ ultra-low temperature freezers.

\subsection{Infections and virus titration}

Cardiomyocytes were infected with SARS-CoV-2 at MOI of 0.1 in CDM3 media without serum. After 1 hour, cells were washed and incubated with complete medium with treatments or not. For virus titration, monolayers of Vero E6 cells $\left(2 \times 10^{4} \mathrm{cell} /\right.$ well) in 96-well plates were infected with serial dilutions of supernatants containing SARSCoV-2 for 1 hour at $37^{\circ} \mathrm{C}$. Semi-solid high glucose DMEM medium containing $2 \%$ FSB and $2.4 \%$ carboxymethylcellulose was added and cultures were incubated for 3 days 
at $37^{\circ} \mathrm{C}$. Then, the cells were fixed with $10 \%$ formalin for $2 \mathrm{~h}$ at room temperature. The cell monolayer was stained with $0.04 \%$ solution of crystal violet in $20 \%$ ethanol for 1 h. Plaque numbers were scored in at least 3 replicates per dilution by independent readers blinded to the experimental group and the virus titers were determined by plaque-forming units (PFU) per milliliter.

\subsection{Immunocytochemistry and fluorescence image analysis}

hiPSC-CMs grown on 96-well plates were fixed using 4\% PFA solution (SigmaAldrich) for $1 \mathrm{~h}$ and stored at $4^{\circ} \mathrm{C}$ until further processing. Cells were washed with $1 \mathrm{X}$ PBS and then incubated with permeabilization/blocking solution $(0.3 \%$ Triton $X$ $100 / 3 \%$ bovine serum albumin) for $1 \mathrm{~h}$. Primary antibodies were diluted in blocking solution and incubated at $4^{\circ} \mathrm{C}$ overnight, namely anti-SARS-CoV-2 convalescent serum from a recovered COVID-19 patient (1:1000); anti-SARS-CoV-2 spike protein monoclonal antibody (SP) (1:500, G632604 - Genetex); anti-cardiac troponin T (cTnT) (1:500, MA5-12960 - Invitrogen) and anti-Sigma1R B-5 (1:100, SC-137075 - Santa Cruz Biotechnology). The use of the convalescent serum from COVID-19 patients was approved by CAAE number: 30650420.4.1001.0008. Next, hiPSC-CMs were washed 3 times with PBS $1 \mathrm{X}$ and incubated with the secondary antibodies diluted in blocking solution: goat anti-Human Alexa Fluor 647 (1:400; A-21445 - Invitrogen) and goat antiMouse Alexa Fluor 488 (1:400; A-11001 - Invitrogen) for $1 \mathrm{~h}$ at room temperature. Actin filaments were stained with Alexa Fluor 568 phalloidin (1:10; A-12380 - Life Technologies) for $1 \mathrm{~h}$. Nuclei were stained with 300 nM 4'-6-diamino-2-phenylindole (DAPI) for 5 minutes and each well was mounted with two drops of $50 \%$ PBS-Glycerol before image acquisition.

For quantitative analysis, images were acquired using Operetta ${ }^{\circledR}$ High-Content Screening System (Perkin Elmer) with a 20x long working distance (WD) objective lens from at least 10 fields per well. For cell surface area measurement, images of Factin stained cardiomyocytes were segmented using Cellpose and the area was measured using NIH ImageJ software (Stringer et al., 2021). For the other analyses, data were evaluated using the Columbus ${ }^{\mathrm{TM}}$ Image Data Storage and Analysis System (Perkin Elmer) for image segmentation and object detection. The fluorescence threshold was set to determine positive and negative cells for each marker. 
Representative immunostaining images were acquired on a Leica TCS-SP8 confocal microscope using a $63 x$ oil-immersion objective lens.

\subsection{Measurements of cell death and inflammatory mediators}

Monolayers of hiPSC-CMs in 96-well plates (70-90\% confluence) were allowed to regain contractility and then were treated with various concentrations of NE-100. Neutral red (N4638 - Sigma-Aldrich) solution was prepared using ultrapure water and centrifuged (600 g for 20 minutes) to remove precipitates of dye crystals. At 72 hours post-treatment, media was removed, cells were washed once with PBS 1x and $200 \mu \mathrm{L}$ of neutral red working solution diluted in hiPSC-CMs medium was added to each well at a final concentration of $25 \mu \mathrm{g} / \mathrm{ml}$. Cells were incubated for $3 \mathrm{~h}$ at $37^{\circ} \mathrm{C}$ to allow uptake of dye into viable cells. Thereafter, media was removed, and cells were washed with PBS $1 x$ followed by the addition of $1 \%$ acetic acid- $49 \%$ ethanol revealing solution. After additional 10 minutes at $37^{\circ} \mathrm{C}$ and gently shaking, the absorbance was measured in the microplate reader spectrophotometer Infinite ${ }^{\circledR}$ M200 PRO (Tecan) at a wavelength of $540 \mathrm{~nm}$. Surviving hiPSC-CMs were estimated by the percentage relative to untreated condition (vehicle) using the mean of 6 technical replicates per experiment.

The levels of IL-6, IL-8 and TNF- $\alpha$ were quantified in the supernatants from uninfected and SARS-CoV-2-infected hiPSC-CMs by ELISA (R\&D Systems), following manufacturer's instructions. Control groups (MOCK and cells infected with Sars-Cov2 only) were also analyzed in Aragao et al., 2021 (in preparation). The results were obtained as picograms per milliliter $(\mathrm{pg} / \mathrm{ml})$ and are expressed as fold-change relative to untreated uninfected control. Cell death of infected cardiomyocytes was determined according to the activity of lactate dehydrogenase (LDH) in the culture supernatants using a CytoTox ${ }^{\circledR}$ Kit (Promega, USA) according to the manufacturer's instructions. Supernatants were centrifuged at 5,000 rpm for 1 minute, to remove cellular debris.

\subsection{Gene expression analysis}

Total RNA was isolated using TRIzol reagent from hiPSC-CMs pellets, according to the manufacturer's recommendations (Thermo Fisher Scientific). After, total RNA was digested with DNase using DNase I, Amplification Grade, following the 
manufacturer's instructions (Invitrogen, Thermo Fisher Scientific). DNase-treated RNA samples $(1 \mu \mathrm{g})$ were converted to complementary DNA (cDNA) using the M-MLV enzyme (Thermo Fisher Scientific).

The reactions to determine gene expression were conducted in three replicates with a final reaction volume of $10 \mu \mathrm{L}$ in MicroAmp Fast Optical 96 Well Reaction Plates (Thermo Fisher Scientific) containing 1X GoTaq qPCR Master Mix (Promega Corporation), 300 nM CXR Reference Dye, final concentration 200nM of each SYBR green designed primers for the following targets: Angiotensin I Converting Enzyme 2 (ACE2; forward: 5'-CGAAGCCGAAGACCTGTTCTA-3'; reverse: 5'GGGCAAGTGTGGACTGTTCC-3'); Natriuretic Peptide A (ANP; forward: 5'CAACGCAGACCTGATGGATTT-3'; reverse: 5'-AGCCCCCGCTTCTTCATTC-3'); and $10 \mathrm{ng}$ of cDNA per reaction. Briefly, the reactions were performed on a StepOnePlus TM Real-Time PCR System thermocycler (Applied Biosystems). Thermal cycling program comprised hold stage at $95^{\circ} \mathrm{C}$ for $3 \mathrm{~min}$, followed by 40 cycling stages at $95^{\circ} \mathrm{C}$ for $15 \mathrm{sec}, 57^{\circ} \mathrm{C}$ for $15 \mathrm{sec}, 72^{\circ} \mathrm{C}$ for $15 \mathrm{sec}$ and melt curve stage $95^{\circ} \mathrm{C}, 15$ $\mathrm{sec} ; 60^{\circ} \mathrm{C}, 1 \mathrm{~min} ; 95^{\circ} \mathrm{C}, 15 \mathrm{sec}$. The relative expression of the genes of interest (GOI) was normalized by endogenous control genes: Glyceraldehyde-3-phosphate Dehydrogenase (GAPDH; forward: 5'-GCCCTCAACGACCACTTTG-3'; reverse: 5'CCACCACCCTGTTGCTGTAG-3') and Hypoxanthine Phosphoribosyl transferase 1 (HPRT-1; forward 5'-CGTCGTGATTAGTGATGATGAACC-3'; reverse: 5'AGAGGGCTACAATGTGATGGC-3'). qPCR data analysis was performed with the $\mathrm{N}_{0}$ method implemented in LinRegPCR v. 2020.0 software, which considers qPCR mean efficiencies estimated by the window-of-linearity method as proposed by Ramakers et al. (2003) and Ruijter et al. (2009) (Ramakers et al., 2003; Ruijter et al., 2009). № values were calculated in LinRegPCR using default parameters and the arithmetic mean of $\mathrm{N}_{0}$ values from GOI were normalized by taking its ratio to the $\mathrm{N}_{0}$ of the geometric mean of the endogenous control genes (REF) GAPDH and HRRT-1 ( $\mathrm{N}_{0} \mathrm{GOI}$ /NoREF).

\subsection{Protein expression}

Media was completely removed from hiPSC-CMs plated on 24-well plates, and $40 \mu \mathrm{L}$ of sample buffer without bromophenol blue $(62.5 \mathrm{mM}$ Tris $-\mathrm{HCl}, \mathrm{pH} 6.8$, 
containing $10 \%$ glycerol, $2 \%$ SDS, and 5\% 2-mercaptoethanol) was added to each well. The lysate was frozen at $-80^{\circ} \mathrm{C}$ until further processing. Next, cell extracts were boiled at $95^{\circ} \mathrm{C}$ for $5 \mathrm{~min}$, centrifuged $16,000 \times \mathrm{g}$ for $15 \mathrm{~min}$ at $4^{\circ} \mathrm{C}$, and the supernatant was collected. Protein content was estimated using the Bio-Rad Protein Assay (\#5000006, Bio-Rad). After the addition of bromophenol blue (0.02\%), extract samples were separated by electrophoresis on an $8 \%$ SDS polyacrylamide gel and transferred to polyvinylidene difluoride (PVDF) membranes.

Western blotting was performed with minor modifications from the originally described (Towbin et al., 1989). Briefly, membranes were blocked in 5\% non-fat milk diluted in Tris-Buffered Saline with $0.1 \%$ Tween-20 (TBS-T) for $1 \mathrm{~h}$ at room temperature. Membranes were then incubated overnight at $4^{\circ} \mathrm{C}$ with primary antibodies (anti-ACE2 (1:1000; MA5-32307 - Thermo Fisher), anti-Sigma-1 R (1:500; SC-137075 - Santa Cruz Biotechnology), anti-actin (1:2000, MAB1501, Millipore); or anti-GAPDH (1:5000; AM4300 -Thermo Fisher) diluted in TBS-T with 5\% non-fat milk. Then, membranes were washed and incubated with peroxidase-conjugated antibodies (goat anti-Mouse IgG ( $\mathrm{H}+\mathrm{L})$, HRP-conjugate (1:10,000, G21040 -Molecular Probes) and Goat anti-Rabbit IgG (H+L) HRP- conjugate (1:10,000, G21234 - Molecular Probes). The signals were developed using ECL Prime Western Blotting System (\#GERPN2232, Sigma) for 5 minutes and chemiluminescence was detected with an Odyssey-FC System ${ }^{\circledR}$ (LI-COR Biosciences).

Stripping protocol was performed to break bonds between the antibodies and the transferred proteins in order to reuse membranes. Briefly, membranes were incubated for three cycles of 10 minutes in a stripping buffer $(\mathrm{pH} 2.2,200 \mathrm{mM}$ glycine, SDS $0.1 \%$ and $1 \%$ Tween-20). Then, the buffer was discarded, the membranes were washed for 5 minutes with PBS (three times) and 5 minutes with $0.1 \%$ TBS-T (three times). Next, membranes were blocked again and proceeded with the abovedescribed steps.

Densitometry analysis was performed using ImageJ software Gel Analysis program and the values obtained represent the ratio of density between the immunodetected protein and the loading control (actin or GAPDH).

\subsection{Beating frequency evaluation}

hiPSC-CMs were plated on 96 -well plates $\left(1.8 \times 10^{4}\right.$ cells per well) and treated with $\mathrm{NE}-1001 \mu \mathrm{M}$ or vehicle (DMSO) before incubating at $37^{\circ} \mathrm{C}$. At 24 - and 48 -hours 
post-treatment, beating frequency was measured by manually counting the synchronous contractions of the monolayer for 60 seconds (beats per minute). Cells were observed using an EVOS cell imaging system (Thermo Fisher Scientific), in brightfield mode. Three wells at a time were counted and then the plates were replaced for 5-10 minutes at the incubator and allowed to regain contractility before resuming counting. Representative videos were recorded using Operetta® High-Content Screening System (Perkin Elmer) for each condition at baseline and $48 \mathrm{~h}$ after treatment with vehicle or NE-100

\subsection{Statistical analysis}

Data are presented as mean values, and error bars indicate the standard error of the mean (S.E.M) from at least three independent experiments. Immunostaining quantification values were analyzed using nested t-test. For the other data, comparisons between two groups were performed with unpaired two-tailed Student's t-test with Welch's correction and between three or more groups, one-way ANOVA with Holm-Sidak post-hoc. Prism v8.0 (GraphPad) was used for data analysis and graphics, where statistical significance was accepted at $P<0.05$. The $P$ values are specified in figure legends and the symbols represent ${ }^{*} p<0.05,{ }^{* *} p<0.01$, ${ }^{* * *} p<0.001,{ }^{* * * *} p<0.0001$. 


\section{REFERENCES}

Abdullah, C.S., Alam, S., Aishwarya, R., Miriyala, S., Panchatcharam, M., Bhuiyan, M.A.N., Peretik, J.M., Orr, A.W., James, J., Osinska, H., Robbins, J., Lorenz, J.N., Bhuiyan, M.S., 2018. Cardiac Dysfunction in the Sigma 1 Receptor Knockout Mouse Associated With Impaired Mitochondrial Dynamics and Bioenergetics. J. Am. Heart Assoc. 7. https://doi.org/10.1161/JAHA.118.009775

Akasaka, Y., Morimoto, N., Ishikawa, Y., Fujita, K., Ito, K., Kimura-Matsumoto, M., Ishiguro, S., Morita, H., Kobayashi, Y., Ishii, T., 2006. Myocardial apoptosis associated with the expression of proinflammatory cytokines during the course of myocardial infarction. Mod. Pathol. 19, 588-598. https://doi.org/10.1038/modpathol.3800568

Aoyagi, T., Matsui, T., 2012. The Cardiomyocyte as a Source of Cytokines in Cardiac Injury. J. Cell Sci. Ther. s5. https://doi.org/10.4172/2157-7013.s5-003

Azkur, A.K., Akdis, M., Azkur, D., Sokolowska, M., van de Veen, W., Brüggen, M.C., O'Mahony, L., Gao, Y., Nadeau, K., Akdis, C.A., 2020. Immune response to SARSCoV-2 and mechanisms of immunopathological changes in COVID-19. Allergy Eur. J. Allergy Clin. Immunol. https://doi.org/10.1111/all.14364

Balasuriya, D., D'Sa, L., Talker, R., Dupuis, E., Maurin, F., Martin, P., Borgese, F., Soriani, O., Edwardson, J.M., 2014. A direct interaction between the sigma-1 receptor and the herg voltage-gated $\mathrm{K}+$ channel revealed by atomic force microscopy and homogeneous time-resolved fluorescence (HTRF®). J. Biol. Chem. 289, 32353-32363. https://doi.org/10.1074/jbc.M114.603506

Belostotskaya, G.B., Golovanova, T.A., 2014. Characterization of contracting cardiomyocyte colonies in the primary culture of neonatal rat myocardial cells: A model of in vitro cardiomyogenesis. Cell Cycle 13, 910-918. https://doi.org/10.4161/cc.27768

Bhuiyan, M.S., Fukunaga, K., 2009. Stimulation of Sigma-1 receptor signaling by dehydroepiandrosterone ameliorates pressure overload-induced hypertrophy and dysfunctions in ovariectomized rats. Expert Opin. Ther. Targets 13, 1253-1265. https://doi.org/10.1517/14728220903264064

Bojkova, D., Wagner, J.U.G., Shumliakivska, M., Aslan, G.S., Saleem, U., Hansen, A., Luxán, G., Günther, S., Pham, M.D., Krishnan, J., Harter, P.N., Ermel, U.H., Frangakis, A.S., Milting, H., Zeiher, A.M., Klingel, K., Cinatl, J., Dendorfer, A., Eschenhagen, T., Tschöpe, C., Ciesek, S., Dimmeler, S., 2020. SARS-CoV-2 infects and induces cytotoxic effects in human cardiomyocytes. Cardiovasc. Res. 116, 2207-2215. https://doi.org/10.1093/cvr/cvaa267

Bulfamante, G. Pietro, Perrucci, G.L., Falleni, M., Sommariva, E., Tosi, D., Martinelli, C., Songia, P., Poggio, P., Carugo, S., Pompilio, G., 2020. Evidence of sars-cov-2 transcriptional activity in cardiomyocytes of covid-19 patients without clinical signs of cardiac involvement. Biomedicines 8, 1-13. https://doi.org/10.3390/biomedicines8120626

Chaudhari, U., Nemade, H., Wagh, V., Gaspar, J.A., Ellis, J.K., Srinivasan, S.P., Spitkovski, D., Nguemo, F., Louisse, J., Bremer, S., Hescheler, J., Keun, H.C., Hengstler, J.G., Sachinidis, A., 2016. Identification of genomic biomarkers for anthracycline-induced cardiotoxicity in human iPSC-derived cardiomyocytes: an in vitro repeated exposure toxicity approach for safety assessment. Arch. Toxicol. 90, 2763-2777. https://doi.org/10.1007/s00204-015-1623-5

Chen, C.Y., Wang, F.L., Lin, C.C., 2006. Chronic hydroxychloroquine use associated with QT prolongation and refractory ventricular arrhythmia. Clin. Toxicol. 44, 173-175. https://doi.org/10.1080/15563650500514558

Choi, S.W., Shin, J.S., Park, S.-J., Jung, E., Park, Y.-G., Lee, J., Kim, S.J., Park, H.-J., Lee, J.-H., Park, S.-M., Moon, S.-H., Ban, K., Go, Y.Y., 2020. Antiviral activity and safety of remdesivir against SARS-CoV-2 infection in human pluripotent stem cell-derived 
bioRxiv preprint doi: https://doi.org/10.1101/2021.02.20.432092; this version posted February 21,2021 . The copyright holder for this

cardiomyocytes. Antiviral Res. 104955. https://doi.org/10.1016/j.antiviral.2020.104955

Corbera, J., Vaño, D., Martínez, D., Vela, J.M., Zamanillo, D., Dordal, A., Andreu, F., Hernandez, E., Perez, R., Escriche, M., Salgado, L., Yeste, S., Serafini, M.T., Pascual, R., Alegre, J., Calvet, M.C., Cano, N., Carro, M., Buschmann, H., Holenz, J., 2006. A medicinal-chemistry-guided approach to selective and druglike sigma 1 ligands. ChemMedChem 1, 140-154. https://doi.org/10.1002/cmdc.200500034

Cottam, E.M., Maier, H.J., Manifava, M., Vaux, L.C., Chandra-Schoenfelder, P., Gerner, W., Britton, P., Ktistakis, N.T., Wileman, T., 2011. Coronavirus nsp6 proteins generate autophagosomes from the endoplasmic reticulum via an omegasome intermediate. Autophagy 7, 1335-1347. https://doi.org/10.4161/auto.7.11.16642

Crottès, D., Martial, S., Rapetti-Mauss, R.L., Pisani, D.F., Loriol, C., Pellissier, B., Martin, P., Chevet, E., Borgese, F., Soriani, O., 2011. Sig1R protein regulates hERG channel expression through a post-translational mechanism in leukemic cells. J. Biol. Chem. 286, 27947-27958. https://doi.org/10.1074/jbc.M111.226738

Cruvinel, E., Ogusuku, I., Cerioni, R., Rodrigues, S., Gonçalves, J., Góes, M.E., Alvim, J.M., Silva, A.C., Lino, V. de S., Boccardo, E., Goulart, E., Pereira, A., Dariolli, R., Valadares, M., Biagi, D., 2020. Long-term single-cell passaging of human iPSC fully supports pluripotency and high-efficient trilineage differentiation capacity. SAGE Open Med. 8, 205031212096645. https://doi.org/10.1177/2050312120966456

Dariolli, R., Campana, C., Gutierrez, A., Sobie, E.A., 2021. In vitro and in silico models to study SARS-CoV-2 infection: integrating experimental and computational tools to mimic \&quot;COVID-19 cardiomyocyte\&quot; Front. Physiol. 12, 119. https://doi.org/10.3389/FPHYS.2021.624185

Eastman, R.T., Roth, J.S., Brimacombe, K.R., Simeonov, A., Shen, M., Patnaik, S., Hall, M.D., 2020. Remdesivir: A Review of Its Discovery and Development Leading to Emergency Use Authorization for Treatment of COVID-19. ACS Cent. Sci. 6, 672-683. https://doi.org/10.1021/acscentsci.0c00489

Ela, C., Barg, J., Vogel, Z., Hasin, Y., Eilam, Y., 1994. Sigma receptor ligands modulate contractility, $\mathrm{Ca}++$ influx and beating rate in cultured cardiac myocytes. J. Pharmacol. Exp. Ther. 269, 1300-1309.

Eng, G., Lee, B.W., Protas, L., Gagliardi, M., Brown, K., Kass, R.S., Keller, G., Robinson, R.B., Vunjak-Novakovic, G., 2016. Autonomous beating rate adaptation in human stem cell-derived cardiomyocytes. Nat. Commun. 7, 1-10. https://doi.org/10.1038/ncomms10312

Friesland, M., Mingorance, L., Chung, J., Chisari, F. V., Gastaminza, P., 2013. Sigma-1 Receptor Regulates Early Steps of Viral RNA Replication at the Onset of Hepatitis C Virus Infection. J. Virol. 87, 6377-6390. https://doi.org/10.1128/jvi.03557-12

Gnecchi, M., Moretti, F., Bassi, E.M., Leonardi, S., Totaro, R., Perotti, L., Zuccaro, V., Perlini, S., Preda, L., Baldanti, F., Bruno, R., Visconti, L.O., 2020. Myocarditis in a 16year-old boy positive for SARS-CoV-2. Lancet 395, e116. https://doi.org/10.1016/S0140-6736(20)31307-6

Gordon, D.E., Jang, G.M., Bouhaddou, M., Xu, J., Obernier, K., White, K.M., O'Meara, M.J., Rezelj, V. V., Guo, J.Z., Swaney, D.L., Tummino, T.A., Hüttenhain, R., Kaake, R.M., Richards, A.L., Tutuncuoglu, B., Foussard, H., Batra, J., Haas, K., Modak, M., Kim, M., Haas, P., Polacco, B.J., Braberg, H., Fabius, J.M., Eckhardt, M., Soucheray, M., Bennett, M.J., Cakir, M., McGregor, M.J., Li, Q., Meyer, B., Roesch, F., Vallet, T., Mac Kain, A., Miorin, L., Moreno, E., Naing, Z.Z.C., Zhou, Y., Peng, S., Shi, Y., Zhang, Z., Shen, W., Kirby, I.T., Melnyk, J.E., Chorba, J.S., Lou, K., Dai, S.A., Barrio-Hernandez, I., Memon, D., Hernandez-Armenta, C., Lyu, J., Mathy, C.J.P., Perica, T., Pilla, K.B., Ganesan, S.J., Saltzberg, D.J., Rakesh, R., Liu, X., Rosenthal, S.B., Calviello, L., Venkataramanan, S., Liboy-Lugo, J., Lin, Y., Huang, X.P., Liu, Y.F., Wankowicz, S.A., Bohn, M., Safari, M., Ugur, F.S., Koh, C., Savar, N.S., Tran, Q.D., Shengjuler, D., Fletcher, S.J., O'Neal, M.C., Cai, Y., Chang, J.C.J., Broadhurst, D.J., Klippsten, S., Sharp, P.P., Wenzell, N.A., Kuzuoglu-Ozturk, D., Wang, H.Y., Trenker, R., Young, J.M., Cavero, D.A., Hiatt, J., Roth, T.L., Rathore, U., Subramanian, A., Noack, J., Hubert, M., 
bioRxiv preprint doi: https://doi.org/10.1101/2021.02.20.432092; this version posted February 21, 2021. The copyright holder for this preprint (which was not certified by peer review) is the author/funder, who has granted bioRxiv a license to display the preprint in perpetuity. It is made available under aCC-BY-ND 4.0 International license.

Stroud, R.M., Frankel, A.D., Rosenberg, O.S., Verba, K.A., Agard, D.A., Ott, M., Emerman, M., Jura, N., von Zastrow, M., Verdin, E., Ashworth, A., Schwartz, O., d'Enfert, C., Mukherjee, S., Jacobson, M., Malik, H.S., Fujimori, D.G., Ideker, T., Craik, C.S., Floor, S.N., Fraser, J.S., Gross, J.D., Sali, A., Roth, B.L., Ruggero, D., Taunton, J., Kortemme, T., Beltrao, P., Vignuzzi, M., García-Sastre, A., Shokat, K.M., Shoichet, B.K., Krogan, N.J., 2020. A SARS-CoV-2 protein interaction map reveals targets for drug repurposing. Nature 583, 459-468. https://doi.org/10.1038/s41586-020-2286-9

Gunning, P.W., Hardeman, E.C., Lappalainen, P., Mulvihill, D.P., 2015. Tropomyosin master regulator of actin filament function in the cytoskeleton. J. Cell Sci. 128, 29652974. https://doi.org/10.1242/jcs. 172502

Hancox, J.C., Mitcheson, J.S., 2006. Combined hERG channel inhibition and disruption of trafficking in drug-induced long QT syndrome by fluoxetine: a case-study in cardiac safety pharmacology. Br. J. Pharmacol. 149, 457-459. https://doi.org/10.1038/sj.bjp.0706890

Hayashi, T., Su, T.P., 2003. $\sigma-1$ receptors ( $\sigma 1$ binding sites) form raft-like microdomains and target lipid droplets on the endoplasmic reticulum: Roles in endoplasmic reticulum lipid compartmentalization and export. J. Pharmacol. Exp. Ther. 306, 718-725. https://doi.org/10.1124/jpet.103.051284

Hirano, K., Tagashira, H., Fukunaga, K., 2014. Cardioprotective Effect of the Selective Sigma-1 Receptor Agonist, SA4503. YAKUGAKU ZASSHI 134, 707-713. https://doi.org/10.1248/yakushi.13-00255-3

Hirata, Y., Yamamoto, H., Atta, M.S.M., Mahmoud, S., Oh-Hashi, K., Kiuchi, K., 2011. Chloroquine inhibits glutamate-induced death of a neuronal cell line by reducing reactive oxygen species through sigma-1 receptor. J. Neurochem. 119, 839-847. https://doi.org/10.1111/j.1471-4159.2011.07464.x

Hoffmann, M., Kleine-Weber, H., Schroeder, S., Krüger, N., Herrler, T., Erichsen, S., Schiergens, T.S., Herrler, G., Wu, N.H., Nitsche, A., Müller, M.A., Drosten, C., Pöhlmann, S., 2020. SARS-CoV-2 Cell Entry Depends on ACE2 and TMPRSS2 and Is Blocked by a Clinically Proven Protease Inhibitor. Cell 181, 271-280.e8. https://doi.org/10.1016/j.cell.2020.02.052

Huang, C., Wang, Y., Li, X., Ren, L., Zhao, J., Hu, Y., Zhang, L., Fan, G., Xu, J., Gu, X., Cheng, Z., Yu, T., Xia, J., Wei, Y., Wu, W., Xie, X., Yin, W., Li, H., Liu, M., Xiao, Y., Gao, H., Guo, L., Xie, J., Wang, G., Jiang, R., Gao, Z., Jin, Q., Wang, J., Cao, B., 2020. Clinical features of patients infected with 2019 novel coronavirus in Wuhan, China. Lancet 395, 497-506. https://doi.org/10.1016/S0140-6736(20)30183-5

Huang, L., Zhao, P., Tang, D., Zhu, T., Han, R., Zhan, C., Liu, W., Zeng, H., Tao, Q., Xia, L., 2020. Cardiac Involvement in Patients Recovered From COVID-2019 Identified Using Magnetic Resonance Imaging. JACC Cardiovasc. Imaging. https://doi.org/10.1016/j.jcmg.2020.05.004

J Alsaadi, E.A., Jones, I.M., 2019. Membrane binding proteins of coronaviruses. Future Virol. 14, 275-286. https://doi.org/10.2217/fvl-2018-0144

Janssen, S.P.M., Gayan-Ramirez, G., Van Den Bergh, A., Herijgers, P., Maes, K., Verbeken, E., Decramer, M., 2005. Interleukin-6 causes myocardial failure and skeletal muscle atrophy in rats. Circulation 111, 996-1005. https://doi.org/10.1161/01.CIR.0000156469.96135.0D

Jug, B., Salobir, B.G., Vene, N., Šebeátjen, M., Šabovič, M., Keber, I., 2009. Interleukin-6 is a stronger prognostic predictor than high-sensitive C-reactive protein in patients with chronic stable heart failure. Heart Vessels 24, 271-276. https://doi.org/10.1007/s00380008-1111-4

Lenze, E.J., Mattar, C., Zorumski, C.F., Stevens, A., Schweiger, J., Nicol, G.E., Miller, J.P., Yang, L., Yingling, M., Avidan, M.S., Reiersen, A.M., 2020. Fluvoxamine vs Placebo and Clinical Deterioration in Outpatients With Symptomatic COVID-19. JAMA 324, 2292. https://doi.org/10.1001/jama.2020.22760

Li, B., Yang, J., Zhao, F., Zhi, L., Wang, X., Liu, L., Bi, Z., Zhao, Y., 2020. Prevalence and impact of cardiovascular metabolic diseases on COVID-19 in China. Clin. Res. Cardiol. 
bioRxiv preprint doi: https://doi.org/10.1101/2021.02.20.432092; this version posted February 21,2021 . The copyright holder for this preprint (which was not certified by peer review) is the author/funder, who has granted bioRxiv a license to display the preprint in perpetuity. It is made available under aCC-BY-ND 4.0 International license.

109, 531-538. https://doi.org/10.1007/s00392-020-01626-9

Li, F., 2016. Structure, Function, and Evolution of Coronavirus Spike Proteins. Annu. Rev. Virol. 3, 237-261. https://doi.org/10.1146/annurev-virology-110615-042301

Li, X., Xu, S., Yu, M., Wang, K., Tao, Y., Zhou, Y., Shi, J., Zhou, M., Wu, B., Yang, Z., Zhang, C., Yue, J., Zhang, Z., Renz, H., Liu, X., Xie, J., Xie, M., Zhao, J., 2020. Risk factors for severity and mortality in adult COVID-19 inpatients in Wuhan. J. Allergy Clin. Immunol. 146, 110-118. https://doi.org/10.1016/j.jaci.2020.04.006

Lindner, D., Fitzek, A., Bräuninger, H., Aleshcheva, G., Edler, C., Meissner, K., Scherschel, K., Kirchhof, P., Escher, F., Schultheiss, H.P., Blankenberg, S., Püschel, K., Westermann, D., 2020. Association of Cardiac Infection with SARS-CoV-2 in Confirmed COVID-19 Autopsy Cases. JAMA Cardiol.

https://doi.org/10.1001/jamacardio.2020.3551

Lovato, E.C.W., Barboza, L.N., Wietzikoski, S., de Souza, A.N.V., Auth, P.A., Junior, A.G., Dos Reis Lívero, F.A., 2020. Repurposing Drugs for the Management of Patients with Confirmed Coronavirus Disease 2019 (COVID-19). Curr. Pharm. Des. https://doi.org/10.2174/1381612826666200707121636

Lu, R., Zhao, X., Li, J., Niu, P., Yang, B., Wu, H., Wang, W., Song, H., Huang, B., Zhu, N., Bi, Y., Ma, X., Zhan, F., Wang, L., Hu, T., Zhou, H., Hu, Z., Zhou, W., Zhao, L., Chen, J., Meng, Y., Wang, J., Lin, Y., Yuan, J., Xie, Z., Ma, J., Liu, W.J., Wang, D., Xu, W., Holmes, E.C., Gao, G.F., Wu, G., Chen, W., Shi, W., Tan, W., 2020. Genomic characterisation and epidemiology of 2019 novel coronavirus: implications for virus origins and receptor binding. Lancet 395, 565-574. https://doi.org/10.1016/S01406736(20)30251-8

Magadum, A., Kishore, R., 2020. Cardiovascular Manifestations of COVID-19 Infection. Cells 9, 2508. https://doi.org/10.3390/cells9112508

Marchiano, S., Hsiang, T.-Y., Higashi, T., Kanna, A., Reinecke, H., Yang, X., Pabon, L., Sniadecki, N.J., Bertero, A., Gale, M., Murry, C.E., 2020. SARS-CoV-2 infects human pluripotent stem cell-derived cardiomyocytes, impairing electrical and mechanical function. bioRxiv 2020.08.30.274464. https://doi.org/10.1101/2020.08.30.274464

Miller, S., Krijnse-Locker, J., 2008. Modification of intracellular membrane structures for virus replication. Nat. Rev. Microbiol. 6, 363-374. https://doi.org/10.1038/nrmicro1890

Mirabelli, C., Wotring, J., Zhang, C., McCarty, S., Fursmidt, R., Frum, T., Kadambi, N., Amin, A., O’Meara, T., Pretto, C., Spence, J., Huang, J., Alysandratos, K., Kotton, D., Handelman, S., Wobus, C., Weatherwax, K., Mashour, G., O’Meara, M., Sexton, J., 2020. Morphological Cell Profiling of SARS-CoV-2 Infection Identifies Drug Repurposing Candidates for COVID-19. bioRxiv Prepr. Serv. Biol. 2020.05.27.117184. https://doi.org/10.1101/2020.05.27.117184

Morales-Lázaro, S.L., González-Ramírez, R., Rosenbaum, T., 2019. Molecular interplay between the sigma-1 receptor, steroids, and ion channels. Front. Pharmacol. 10. https://doi.org/10.3389/fphar.2019.00419

Mori, T., Hayashi, T., Hayashi, E., Su, T.P., 2013. Sigma-1 Receptor Chaperone at the ERMitochondrion Interface Mediates the Mitochondrion-ER-Nucleus Signaling for Cellular Survival. PLoS One 8. https://doi.org/10.1371/journal.pone.0076941

Nicin, L., Abplanalp, W.T., Mellentin, H., Kattih, B., Tombor, L., John, D., Schmitto, J.D., Heineke, J., Emrich, F., Arsalan, M., Holubec, T., Walther, T., Zeiher, A.M., Dimmeler, S., 2020. Cell type-specific expression of the putative SARS-CoV-2 receptor ACE2 in human hearts. Eur. Heart J. 41, 1804-1806. https://doi.org/10.1093/eurheartj/ehaa311

Niehoff, J., Matzkies, M., Nguemo, F., Hescheler, J., Reppel, M., 2019. The Effect of Antiarrhythmic Drugs on the Beat Rate Variability of Human Embryonic and Human Induced Pluripotent Stem Cell Derived Cardiomyocytes. Sci. Rep. 9, 1-10. https://doi.org/10.1038/s41598-019-50557-7

Novakova, M., Ela, C., Barg, J., Vogel, Z., Hasin, Y., Eilam, Y., 1995. Inotropic action of $\sigma$ receptor ligands in isolated cardiac myocytes from adult rats. Eur. J. Pharmacol. 286, 19-30. https://doi.org/10.1016/0014-2999(95)00424-J

Nymo, S.H., Hulthe, J., Ueland, T., McMurray, J., Wikstrand, J., Askevold, E.T., Yndestad, 
bioRxiv preprint doi: https://doi.org/10.1101/2021.02.20.432092; this version posted February 21,2021 . The copyright holder for this

A., Gullestad, L., Aukrust, P., 2014. Inflammatory cytokines in chronic heart failure: Interleukin-8 is associated with adverse outcome. Results from CORONA. Eur. J. Heart Fail. 16, 68-75. https://doi.org/10.1093/eurjhf/hft125

Okuyama, S., Imagawa, Y., Ogawa, S. ichi, Araki, H., Ajima, A., Tanaka, M., Muramatsu, M., Nakazato, A., Yamaguchi, K., Yoshida, M., Otomo, S., 1993. NE-100, a novel sigma receptor ligand: In vivo tests. Life Sci. 53. https://doi.org/10.1016/0024-3205(93)90588$\mathrm{T}$

Page, R.L., O'bryant, C.L., Cheng, D., Dow, T.J., Ky, B., Stein, C.M., Spencer, A.P., Trupp, R.J., Lindenfeld, J.A., 2016. Drugs that may cause or exacerbate heart failure. Circulation 134, e32-e69. https://doi.org/10.1161/CIR.0000000000000426

Patel, V.B., Zhong, J.C., Grant, M.B., Oudit, G.Y., 2016. Role of the ACE2/angiotensin 1-7 axis of the renin-angiotensin system in heart failure. Circ. Res. 118, 1313-1326. https://doi.org/10.1161/CIRCRESAHA.116.307708

Pérez-Bermejo, J.A., Kang, S., Rockwood, S.J., Simoneau, C.R., Joy, D.A., Ramadoss, G.N., Silva, A.C., Flanigan, W.R., Li, H., Nakamura, K., Whitman, J.D., Ott, M., Conklin, B.R., Mcdevitt, T.C., 2020. SARS-CoV-2 infection of human iPSC-derived cardiac cells predicts novel cytopathic features in hearts of COVID-19 patients. bioRxiv 2020.08.25.265561. https://doi.org/10.1101/2020.08.25.265561

Pointon, A., Harmer, A.R., Dale, I.L., Abi-Gerges, N., Bowes, J., Pollard, C., Garside, H., 2015. Assessment of cardiomyocyte contraction in human-induced pluripotent stem cell-derived cardiomyocytes. Toxicol. Sci. 144, 227-237. https://doi.org/10.1093/toxsci/kfu312

Ramakers, C., Ruijter, J.M., Lekanne Deprez, R.H., Moorman, A.F.M., 2003. Assumptionfree analysis of quantitative real-time polymerase chain reaction (PCR) data. Neurosci. Lett. 339, 62-66. https://doi.org/10.1016/S0304-3940(02)01423-4

Reznikov, L.R., Norris, M.H., Vashisht, R., Bluhm, A.P., Li, D., Liao, Y.S.J., Brown, A., Butte, A.J., Ostrov, D.A., 2020. Identification of antiviral antihistamines for COVID-19 repurposing. Biochem. Biophys. Res. Commun. https://doi.org/10.1016/j.bbrc.2020.11.095

Ritzenthaler, C., Elamawi, R., 2006. The ER in replication of positive-strand RNA viruses. Plant Cell Monogr. 4, 309-330. https://doi.org/10.1007/7089_061

Rosen, D.A., Seki, S.M., Fernández-Castañeda, A., Beiter, R.M., Eccles, J.D., Woodfolk, J.A., Gaultier, A., 2019a. Modulation of the sigma-1 receptor-IRE1 pathway is beneficial in preclinical models of inflammation and sepsis. Sci. Transl. Med. 11. https://doi.org/10.1126/scitransImed.aau5266

Rosen, D.A., Seki, S.M., Fernández-Castañeda, A., Beiter, R.M., Eccles, J.D., Woodfolk, J.A., Gaultier, A., 2019b. Modulation of the sigma-1 receptor-IRE1 pathway is beneficial in preclinical models of inflammation and sepsis. Sci. Transl. Med. 11. https://doi.org/10.1126/scitranslmed.aau5266

Rothenbacher, D., Müller-Scholze, S., Herder, C., Koenig, W., Kolb, H., 2006. Differential expression of chemokines, risk of stable coronary heart disease, and correlation with established cardiovascular risk markers. Arterioscler. Thromb. Vasc. Biol. 26, 194-199. https://doi.org/10.1161/01.ATV.0000191633.52585.14

Ruijter, J.M., Ramakers, C., Hoogaars, W.M.H., Karlen, Y., Bakker, O., van den hoff, M.J.B., Moorman, A.F.M., 2009. Amplification efficiency: Linking baseline and bias in the analysis of quantitative PCR data. Nucleic Acids Res. 37. https://doi.org/10.1093/nar/gkp045

Sacramento, C.Q., Fintelman-Rodrigues, N., Temerozo, J.R., Dias, S. da S.G., Ferreira, A.C., Mattos, M., Pao, C.R.R., Freitas, C.S. de, Soares, V.C., Bozza, F.A., Bou-Habib, D.C., Bozza, P.T., Souza, T.M.L., 2020. The in vitro antiviral activity of the anti-hepatitis $\mathrm{C}$ virus (HCV) drugs daclatasvir 2 and sofosbuvir against SARS-CoV-2. bioRxiv 2020.06.15.153411. https://doi.org/10.1101/2020.06.15.153411

Santerre, M., Arjona, S.P., Allen, C.N., Shcherbik, N., Sawaya, B.E., 2020. Why do SARSCoV-2 NSPs rush to the ER? J. Neurol. 1, 3. https://doi.org/10.1007/s00415-02010197-8 
bioRxiv preprint doi: https://doi.org/10.1101/2021.02.20.432092; this version posted February 21, 2021. The copyright holder for this

Scialo, F., Daniele, A., Amato, F., Pastore, L., Matera, M.G., Cazzola, M., Castaldo, G., Bianco, A., 2020. ACE2: The Major Cell Entry Receptor for SARS-CoV-2. Lung 198, 867-877. https://doi.org/10.1007/s00408-020-00408-4

Sequeira, V., Nijenkamp, L.L.A.M., Regan, J.A., Van Der Velden, J., 2014. The physiological role of cardiac cytoskeleton and its alterations in heart failure. Biochim. Biophys. Acta Biomembr. 1838, 700-722. https://doi.org/10.1016/j.bbamem.2013.07.011

Shang, J., Ye, G., Shi, K., Wan, Y., Luo, C., Aihara, H., Geng, Q., Auerbach, A., Li, F., 2020. Structural basis of receptor recognition by SARS-CoV-2. Nature 581, 221-224. https://doi.org/10.1038/s41586-020-2179-y

Sharma, A., Garcia, G., Wang, Y., Plummer, J.T., Morizono, K., Arumugaswami, V., Svendsen, C.N., 2020. Human iPSC-Derived Cardiomyocytes Are Susceptible to SARS-CoV-2 Infection. Cell Reports Med. 1, 100052. https://doi.org/10.1016/j.xcrm.2020.100052

Shi, S., Qin, M., Shen, B., Cai, Y., Liu, T., Yang, F., Gong, W., Liu, X., Liang, J., Zhao, Q., Huang, H., Yang, B., Huang, C., 2020. Association of Cardiac Injury with Mortality in Hospitalized Patients with COVID-19 in Wuhan, China. JAMA Cardiol. 5. https://doi.org/10.1001/jamacardio.2020.0950

Shinoda, Y., Tagashira, H., Bhuiyan, M.S., Hasegawa, H., Kanai, H., Fukunaga, K., 2016a. Haloperidol aggravates transverse aortic constriction-induced heart failure via mitochondrial dysfunction. J. Pharmacol. Sci. 131, 172-183.

https://doi.org/10.1016/j.jphs.2016.05.012

Shinoda, Y., Tagashira, H., Bhuiyan, M.S., Hasegawa, H., Kanai, H., Zhang, C., Han, F., Fukunaga, K., 2016b. Corticosteroids mediate heart failure-induced depression through reduced $\sigma 1$-receptor expression. PLoS One 11. https://doi.org/10.1371/journal.pone.0163992

Stracina, T., Slaninova, I., Polanska, H., Axmanova, M., Olejnickova, V., Konecny, P., Masarik, M., Krizanova, O., Novakova, M., 2015. Long-term haloperidol treatment prolongs QT interval and increases expression of sigma 1 and IP3 receptors in guinea pig hearts. Tohoku J. Exp. Med. 236, 199-207. https://doi.org/10.1620/tjem.236.199

Stringer, C., Wang, T., Michaelos, M., Pachitariu, M., 2021. Cellpose: a generalist algorithm for cellular segmentation. Nat. Methods 18, 100-106. https://doi.org/10.1038/s41592020-01018-x

Su, T.P., Hayashi, T., Maurice, T., Buch, S., Ruoho, A.E., 2010. The sigma-1 receptor chaperone as an inter-organelle signaling modulator. Trends Pharmacol. Sci. 31, 557566. https://doi.org/10.1016/j.tips.2010.08.007

Szabo, A., Kovacs, A., Frecska, E., Rajnavolgyi, E., 2014. Psychedelic N,Ndimethyltryptamine and 5-methoxy-N,N-dimethyltryptamine modulate innate and adaptive inflammatory responses through the sigma-1 receptor of human monocytederived dendritic cells. PLoS One 9, e106533. https://doi.org/10.1371/journal.pone.0106533

Tagashira, H., Fukunaga, K., 2012. Cardioprotective Effect of Fluvoxamine, Sigma-1 Receptor High Affinity Agonist. YAKUGAKU ZASSHI 132, 167-172. https://doi.org/10.1248/yakushi.132.167

Tagashira, H., Zhang, C., Lu, Y.M., Hasegawa, H., Kanai, H., Han, F., Fukunaga, K., 2013. Stimulation of $\sigma 1$-receptor restores abnormal mitochondrial $\mathrm{Ca} 2+$ mobilization and ATP production following cardiac hypertrophy. Biochim. Biophys. Acta - Gen. Subj. 1830, 3082-3094. https://doi.org/10.1016/j.bbagen.2012.12.029

Tarabová, B., Nováková, M., Lacinová, L., 2009. Haloperidol moderately inhibits cardiovascular L-type calcium current. Gen. Physiol. Biophys. 28, 249-259. https://doi.org/10.4149/gpb_2009_03_249

Tesei, A., Cortesi, M., Zamagni, A., Arienti, C., Pignatta, S., Zanoni, M., Paolillo, M., Curti, D., Rui, M., Rossi, D., Collina, S., 2018. Sigma receptors as endoplasmic reticulum stress "gatekeepers" and their modulators as emerging new weapons in the fight against cancer. Front. Pharmacol. 9. https://doi.org/10.3389/fphar.2018.00711

Towbin, H., Gordon, J., Staehelin, T., 1989. Immunoblotting in the Clinical Laboratory. J. 
bioRxiv preprint doi: https://doi.org/10.1101/2021.02.20.432092; this version posted February $21,2021$. The copyright holder for this preprint (which was not certified by peer review) is the author/funder, who has granted bioRxiv a license to display the preprint in perpetuity. It is made available under aCC-BY-ND 4.0 International license.

Clin. Chem. Lab. Med. 27, 495-502. https://doi.org/10.1515/cclm.1989.27.8.495

Troncone, L.R., 2020. COVID-19, cytokine storm and sigma-1 receptors: potential treatments at hand? Authorea Prepr. https://doi.org/10.22541/AU.159335613.31156244/V2

Van der Velden, J., Papp, Z., Zaremba, R., Boontje, N.M., De Jong, J.W., Owen, V.J., Burton, P.B.J., Goldmann, P., Jaquet, K., Stienen, G.J.M., 2003. Increased Ca2+sensitivity of the contractile apparatus in end-stage human heart failure results from altered phosphorylation of contractile proteins. Cardiovasc. Res. 57, 37-47. https://doi.org/10.1016/S0008-6363(02)00606-5

Vela, J.M., 2020. Repurposing Sigma-1 Receptor Ligands for COVID-19 Therapy? Front. Pharmacol. 11, 1716. https://doi.org/10.3389/fphar.2020.582310

Vincent, J.L., Taccone, F.S., 2020. Understanding pathways to death in patients with COVID-19. Lancet Respir. Med. 8, 430-432. https://doi.org/10.1016/S22132600(20)30165-X

Watkins, S.J., Borthwick, G.M., Oakenfull, R., Robson, A., Arthur, H.M., 2012. Angiotensin IIinduced cardiomyocyte hypertrophy in vitro is TAK1-dependent and Smad2/3independent. Hypertens. Res. 35, 393-398. https://doi.org/10.1038/hr.2011.196

Witchel, H.J., 2011. Drug-induced hERG Block and Long QT Syndrome. Cardiovasc. Ther. 29, 251-259. https://doi.org/10.1111/j.1755-5922.2010.00154.x

Wong, C.K., Luk, H.K.H., Lai, W.H., Lau, Y.M., Zhang, R.R., Wong, A.C.P., Lo, G.C.S., Chan, K.H., Hung, I.F.N., Tse, H.F., Woo, P.C.Y., Lau, S.K.P., Siu, C.W., 2020. Humaninduced pluripotent stem cell-derived cardiomyocytes platform to study SARS-CoV-2 related myocardial injury. Circ. J. 84, 2027-2031. https://doi.org/10.1253/circj.CJ-200881

Wu, L., O'Kane, A.M., Peng, H., Bi, Y., Motriuk-Smith, D., Ren, J., 2020. SARS-CoV-2 and cardiovascular complications: From molecular mechanisms to pharmaceutical management. Biochem. Pharmacol. 178. https://doi.org/10.1016/j.bcp.2020.114114

Xu, D., Ma, M., Xu, Y., Su, Y., Ong, S.-B., Hu, X., Chai, M., Zhao, M., Li, H., Chen, Y., Xu, X., 2020. Single-cell Transcriptome Analysis Indicates New Potential Regulation Mechanism of ACE2 and NPs signaling among heart failure patients infected with SARS-CoV-2. medRxiv Prepr. Serv. Heal. Sci. https://doi.org/10.1101/2020.04.30.20081257

Yang, J., Chen, T., Zhou, Y., 2021. Mediators of SARS-CoV-2 entry are preferentially enriched in cardiomyocytes. Hereditas 158, 4. https://doi.org/10.1186/s41065-02000168-4

Yang, J., Zheng, Y., Gou, X., Pu, K., Chen, Z., Guo, Q., Ji, R., Wang, H., Wang, Y., Zhou, Y., 2020. Prevalence of comorbidities and its effects in coronavirus disease 2019 patients: A systematic review and meta-analysis. Int. J. Infect. Dis. 94, 91-95. https://doi.org/10.1016/j.ijid.2020.03.017

Yao, X.H., Li, T.Y., He, Z.C., Ping, Y.F., Liu, H.W., Yu, S.C., Mou, H.M., Wang, L.H., Zhang, H.R., Fu, W.J., Luo, T., Liu, F., Chen, C., Xiao, H.L., Guo, H.T., Lin, S., Xiang, D.F., Shi, Y., Li, Q.R., Huang, X., Cui, Y., Li, X.Z., Tang, W., Pan, P.F., Huang, X.Q., Ding, Y.Q., Bian, X.W., 2020. [A pathological report of three COVID-19 cases by minimally invasive autopsies]. Zhonghua bing li xue za zhi = Chinese J. Pathol. 49, E009. https://doi.org/10.3760/cma.j.cn112151-20200312-00193

Yiangou, L., Davis, R.P., Mummery, C.L., 2020. Using Cardiovascular Cells from Human Pluripotent Stem Cells for COVID-19 Research: Why the Heart Fails. Stem Cell Reports. https://doi.org/10.1016/j.stemcr.2020.11.003

Youker, K., Smith, C.W., Anderson, D.C., Miller, D., Michael, L.H., Rossen, R.D., Entman, M.L., 1992. Neutrophil adherence to isolated adult cardiac myocytes: Induction by cardiac lymph collected during ischemia and reperfusion. J. Clin. Invest. 89, 602-609. https://doi.org/10.1172/JCl115626

Yu, Z., IJzerman, A.P., Heitman, L.H., 2015. Kv11.1 (hERG)-induced cardiotoxicity: A molecular insight from a binding kinetics study of prototypical Kv11.1 (hERG) inhibitors. Br. J. Pharmacol. 172, 940-955. https://doi.org/10.1111/bph.12967 
bioRxiv preprint doi: https://doi.org/10.1101/2021.02.20.432092; this version posted February 21, 2021. The copyright holder for this preprint (which was not certified by peer review) is the author/funder, who has granted bioRxiv a license to display the preprint in perpetuity. It is made available under aCC-BY-ND 4.0 International license.

Zhou, R., Chen, S.H., Li, G., Chen, H.L., Liu, Y.X., Wu, H.M., Wang, Y., Feng, J., Hong, J.S., 2019. Ultralow doses of dextromethorphan protect mice from endotoxin-induced sepsislike hepatotoxicity. Chem. Biol. Interact. 303, 50-56.

https://doi.org/10.1016/j.cbi.2019.02.025 